\title{
Synthesis, Characterization, Antimicrobial, DNA Cleavage, and Antioxidant Studies of Some Metal Complexes Derived from Schiff Base Containing Indole and Quinoline Moieties
}

\author{
Mahendra Raj Karekal, Vivekanand Biradar, \\ and Mruthyunjayaswamy Bennikallu Hire Mathada \\ Department of Studies and Research in Chemistry, Gulbarga University, Gulbarga-585 106, Karnataka, India \\ Correspondence should be addressed to Mruthyunjayaswamy Bennikallu Hire Mathada; bhmmswamy53@rediffmail.com
}

Received 22 April 2013; Accepted 28 July 2013

Academic Editor: Claudio Pettinari

Copyright (C) 2013 Mahendra Raj Karekal et al. This is an open access article distributed under the Creative Commons Attribution License, which permits unrestricted use, distribution, and reproduction in any medium, provided the original work is properly cited.

A new Schiff base of 5-chloro-3-phenyl-1H-indole-2-carboxyhydrazide and 3-formyl-2-hydroxy-1H-quinoline (HL), and its Cu(II), $\mathrm{Co}(\mathrm{II}), \mathrm{Ni}(\mathrm{II}), \mathrm{Zn}(\mathrm{II}), \mathrm{Cd}(\mathrm{II})$, and $\mathrm{Hg}(\mathrm{II})$ complexes have been synthesized and characterized in the light of microanalytical, IR, ${ }^{1} \mathrm{H}$ NMR, UV-Vis, FAB-mass, ESR, XRD, and TGA spectral studies. The magnetic susceptibility measurements and low conductivity data provide evidence for monomeric and neutral nature of the complexes. On the basis of spectral studies and analytical data, it is evident that the Schiff base acts as tridentate ligand. The $\mathrm{Cu}(\mathrm{II}), \mathrm{Co}(\mathrm{II})$, and $\mathrm{Ni}(\mathrm{II})$ complexes were octahedral, whereas $\mathrm{Zn}(\mathrm{II}), \mathrm{Cd}(\mathrm{II})$, and $\mathrm{Hg}$ (II) complexes were tetrahedral in nature. The redox behavior of the $\mathrm{Cu}$ (II) complex was investigated by electrochemical method using cyclic voltammetry. In order to evaluate the effect of metal ions upon chelation, both the ligand and its metal complexes were screened for their antibacterial and antifungal activities by minimum inhibitory concentration (MIC) method. The DNA cleavage experiment performed using agarose gel electrophoresis method showed the cleavage of DNA by all the metal complexes. The free radical scavenging activity of newly synthesized compounds has been determined at a different concentration range by means of their interaction with the stable free radical 1,1-diphenyl-2-picrylhydrazyl (DPPH).

\section{Introduction}

Numerous indole-containing natural and synthetic products such as reserpine, vincristine, indolemycin, mitomycin, pindolol, dolasetron mesylate, indomethacin, or sumatriptan are being used for the treatment of various illnesses. Therefore, indole structure represents a highly relevant heterocyclic system. Many pharmacodynamic compounds containing indole nucleus have been reported to possess a wide variety of biological properties, namely, anti-inflammatory $[1,2]$, anticonvulsant [3], cardiovascular [4], antibacterial [5], COX-2 inhibitor [6,7], and antiviral activities [8]. More specifically, several reports describe that indole-2-carbohydrazides and related compounds are endowed with antihistaminic [9], antidepressant [10], and MAO inhibitory activities [11]. Particularly, the compounds having three substituted indole nucleus are being used as the starting materials for the synthesis of number of alkaloids, agrochemicals, pharmaceuticals, and perfumes [12].

Quinoline derivatives have also attracted the attention of the chemists because of their presence in many natural products possessing significant biological activities [13-17]. Smallmolecule interactions with DNA continue to be intensely and widely studied for their usefulness as probes of cellular replication and transcriptional regulation and for their potential as pharmaceuticals. The $\mathrm{Cu}$ (II) complexes have been reported to be active in DNA strand scissors [18]. On the other hand, an increasing interest in antioxidant, particularly in those intended to prevent the mischievous effects caused by the free radicals in the human body is an attracting one. The free radicals are also believed to be associated with carcinogenesis, mutagenesis, arthritis, diabetes, inflammation, cancer, and 
genotoxicity due to the oxidative stress which arises as a result of imbalance between free radical generations $[19,20]$. The antioxidant activity of metal complex is found to be induced by both the identity of the metal and the ligands bound to it [21]. The development of new metal-containing antioxidant agents have been reported by several research groups [22]. Based on these findings and in continuation of our research work on coordination chemistry [23-28], we describe the synthesis of a new Schiff base and its metal complexes with 5chloro-3-phenyl- $1 \mathrm{H}$-indole-2-carboxyhydrazide fused to 3formyl-2-hydroxy-1H-quinoline with the aim of obtaining more potent pharmacological active compounds.

\section{Experimental}

2.1. Analysis and Physical Measurements. IR Spectra of the synthesized Schiff base and its metal complexes were recorded in $\mathrm{KBr}$ pellets on a Perkin-Elmer FT-IR instrument in the range $4000-350 \mathrm{~cm}^{-1} .{ }^{1} \mathrm{H}$ NMR spectra were recorded in $d_{6}$-DMSO using a Bruker DRX-400 MHz instrument. UVVisible spectra of the $\mathrm{Cu}(\mathrm{II}), \mathrm{Co}(\mathrm{II})$, and $\mathrm{Ni}(\mathrm{II})$ complexes were recorded on Elico-SL 164 spectrometer in the range 200-1000 $\mathrm{nm}$ in DMF solution $\left(1 \times 10^{-3} \mathrm{M}\right)$. The FAB mass spectra of ligand and its $\mathrm{Cu}(\mathrm{II})$ and $\mathrm{Zn}$ (II) complexes were recorded on a JEOL SX 102/DA-6000 mass spectrometer/data system using argon/xenon $(6 \mathrm{kV}, 10 \mathrm{~mA})$ as the FAB gas. The accelerating voltage was $10 \mathrm{kV}$ and the spectra were recorded at room temperature using $\mathrm{m}$-nitrobenzyl alcohol (NBA) as the matrix. Elemental analysis was obtained from HERAEUS $\mathrm{C}, \mathrm{H}$, and $\mathrm{N}-\mathrm{O}$ rapid analyzer, and metal analysis was carried out by following the standard methods. ESR measurement was carried out on a BRUKER BioSpin Gmbh spectrometer working at microwave frequency of $9.903 \mathrm{GHz}$. Electrochemistry of the $\mathrm{Cu}$ (II) complex was recorded on a $600 \mathrm{D}$ series model electrochemical analyzer in DMF using $n$ $\mathrm{Bu}_{4} \mathrm{~N}-\mathrm{ClO}_{4}$ as a supporting electrolyte. The experiment was carried out by using DPPH as reference with field set at 3200 gauss. Magnetic susceptibility measurements were made at room temperature on a Gouy balance using $\mathrm{Hg}\left[\mathrm{Co}(\mathrm{NCS})_{4}\right]$ as the calibrant.

2.2. Methods. All the chemicals used were of reagent grade and procured from Hi-media and Sigma Aldrich. Solvents were dried and distilled before use. Melting points of the newly synthesized compounds were determined by electrothermal apparatus using open capillary tubes. The metal and chloride contents were determined as per standard procedures [29]. The precursors 5-chloro-3-phenyl- $1 H$-indole2-carboxyhydrazide and 3-formyl-2-hydroxy- $1 H$-quinoline were prepared by the literature methods $[16,30]$.

2.3. Synthesis of the Schiff Base HL. Equimolar mixture of 5chloro-3-phenyl-1H-indole-2-carboxyhydrazide $(0.001 \mathrm{~mol})$ and 3-formyl- 2-hydroxy- $1 \mathrm{H}$-quinoline $(0.001 \mathrm{~mol})$ with a catalytic amount of glacial acetic acid (1-2 drops) in ethanol $(20 \mathrm{~mL})$ was refluxed on a water bath for about $7-8 \mathrm{~h}$. The reaction was monitored by TLC. The pale yellow solid separated was filtered, washed with little ethanol, dried, and

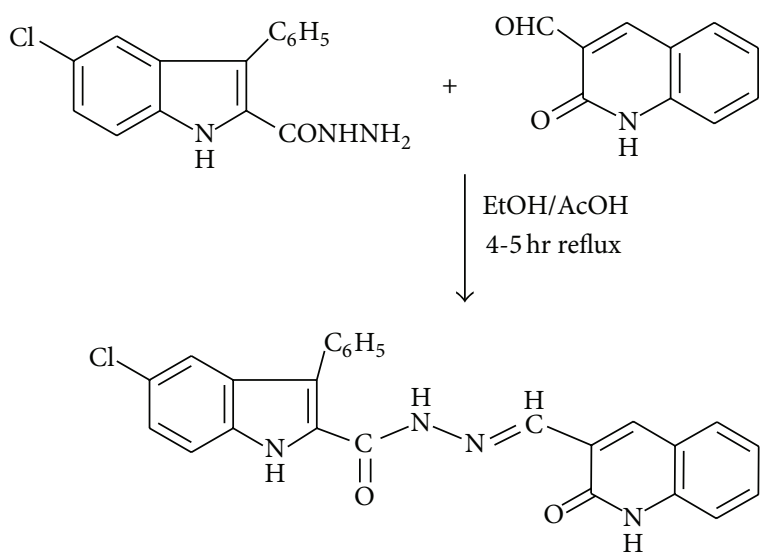

Scheme 1: Synthesis of Schiff base ligand HL.

recrystallized from dioxane (Scheme 1). Yield: 65\%; m.p. $314^{\circ} \mathrm{C}$. Anal. Calcd. for $\mathrm{C}_{25} \mathrm{H}_{17} \mathrm{O}_{2} \mathrm{~N}_{4} \mathrm{Cl}(\mathrm{Mr}=440)$ : C, 68.10; $\mathrm{H}, 3.85$; N, 12.71\%. Found: C, 68.25; H, 3.91; N, 12.89\%. IR $\left(\mathrm{KBr}, \mathrm{cm}^{-1}\right): 3311,3229$, and $3162\left(\nu_{\mathrm{NH} / \mathrm{NH}}\right) ; 1674$ and 1661 $\left(\nu_{\mathrm{C}=\mathrm{O}}\right) ; 1608\left(\nu_{\mathrm{C}=\mathrm{N}}\right) ;{ }^{1} \mathrm{H}$ NMR (DMSO- $\left.d_{6}\right): \delta 12.20$ and 12.00 (s, 2H, two CONH); 11.60 (s, 1H, indole $\mathrm{NH}) ; 8.40$ (s, $1 \mathrm{H}$, $\mathrm{HC}=\mathrm{N}) ; 7.10-8.20$ (m, 13H, ArH).

2.4. Preparation of $\mathrm{Cu}(\mathrm{II}), \mathrm{Co}(\mathrm{II}), \mathrm{Ni}(\mathrm{II}), \mathrm{Zn}(\mathrm{II}), \mathrm{Cd}(\mathrm{II})$, and $\mathrm{Hg}(\mathrm{II})$ Complexes of Schiff Base HL. To the hot solution of 5-chloro- $N$ - $\left(2^{\prime}\right.$-dihydro- $2^{\prime}$-oxoquinolin- $3^{\prime}$-yl methylene)3 -phenyl- $1 H$-indole-2-carbohydrazide (HL) $(0.002 \mathrm{~mol})$ in ethanol $(30 \mathrm{~mL})$ was added a hot ethanolic solution $(15 \mathrm{~mL})$ of respective metal chlorides $(0.002 \mathrm{~mol})$. The reaction mixture was refluxed on a steam bath for about $4 \mathrm{~h}$, during which no solid separated out. An aqueous alcoholic solution of sodium acetate $(0.5 \mathrm{~g})$ was added to the reaction mixture to maintain a $\mathrm{pH}$ of about 6.0-7.0 and reflux was continued for about an hour. The reaction mixture was poured in the distilled water. The separated solid complexes were collected by filtration, washed with sufficient quantity of distilled water, then with hot ethanol to apparent dryness, and dried in a vacuum over anhydrous calcium chloride in a desiccator. The melting points of all the compounds are reported in Table 1.

\subsubsection{Cu(II) Complex of Schiff Base HL}

Green Solid. Yield: 70\%; m.p. > $340^{\circ} \mathrm{C}$; Anal. Calcd. for $\left[\mathrm{Cu}\left(\mathrm{C}_{50} \mathrm{H}_{32} \mathrm{O}_{4} \mathrm{~N}_{8} \mathrm{Cl}_{2}\right)\right] \mathrm{H}_{2} \mathrm{O}(\mathrm{Mr}=959.54)$ : C, 62.46; H, 3.53; $\mathrm{N}, 11.66 \%$. Found: C, 62.59; H, 3.32; N, 11.74\%. IR $\left(\mathrm{KBr}, \mathrm{cm}^{-1}\right)$ : $3418\left(\nu_{\mathrm{H}_{2} \mathrm{O}}\right) ; 3283$ and $3221\left(\nu_{\mathrm{NH} / \mathrm{NH}}\right) ; 1639\left(\nu_{\mathrm{C}=\mathrm{O}}\right) ; 1548\left(\nu_{\mathrm{C}=\mathrm{N}}\right)$; 1493, 1077 and $615\left(\nu_{\text {Pyridine ring }}\right) ; 514\left(\nu_{\mathrm{M}-\mathrm{O}}\right) ; 442\left(\nu_{\mathrm{M}-\mathrm{N}}\right)$. UVVis $\left(\mathrm{cm}^{-1}\right): \nu_{2}, 13769-17463$.

\subsubsection{Co(II) Complex of Schiff Base HL}

Light Brown Solid. Yield: 77\%; m.p. > 340 ${ }^{\circ}$; Anal. Calcd. for $\left[\mathrm{Co}\left(\mathrm{C}_{50} \mathrm{H}_{32} \mathrm{O}_{4} \mathrm{~N}_{8} \mathrm{Cl}_{2}\right)\right] \mathrm{H}_{2} \mathrm{O}(\mathrm{Mr}=954.93): \mathrm{C}, 62.76 ; \mathrm{H}, 3.55$; $\mathrm{N}, 11.71 \%$. Found: C, $62.92 ; \mathrm{H}, 3.82 ; \mathrm{N}, 11.86 \%$. IR $\left(\mathrm{KBr}, \mathrm{cm}^{-1}\right)$ : $3423\left(\nu_{\mathrm{H}_{2} \mathrm{O}}\right) ; 3271$ and $3230\left(\nu_{\mathrm{NH} / \mathrm{NH}}\right) ; 1629\left(\nu_{\mathrm{C}=\mathrm{O}}\right) ; 1551\left(\nu_{\mathrm{C}=\mathrm{N}}\right)$; 


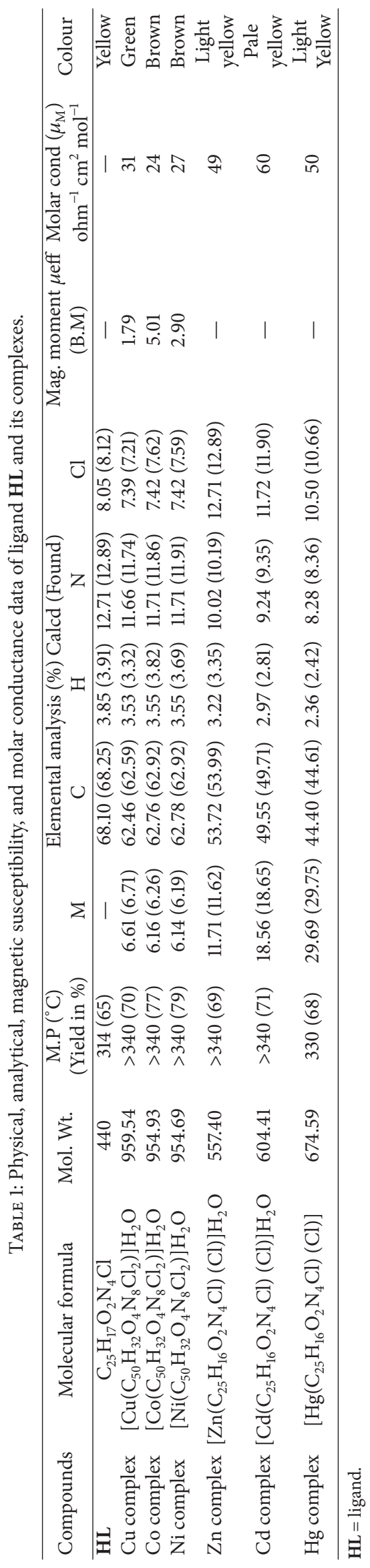


1489, 1061 and $670\left(\nu_{\text {Pyridine ring }}\right) ; 553\left(\nu_{\mathrm{M}-\mathrm{O}}\right) ; 435\left(\nu_{\mathrm{M}-\mathrm{N}}\right)$. UVVis $\left(\mathrm{cm}^{-1}\right): v_{1}, 7447 ; v_{2}, 15977 ; v_{3}, 19518$.

\subsubsection{Ni(II) Complex of Schiff Base HL}

Brown Solid. Yield: 79\%; m.p. > 340 C; Anal. Calcd. for $\left[\mathrm{Ni}\left(\mathrm{C}_{50} \mathrm{H}_{32} \mathrm{O}_{4} \mathrm{~N}_{8} \mathrm{Cl}_{2}\right)\right] \mathrm{H}_{2} \mathrm{O}(\mathrm{Mr}=954.69): \mathrm{C}, 62.78 ; \mathrm{H}, 3.55$; $\mathrm{N}, 11.71 \%$. Found: C, 62.92; H, 3.69; N, 11.91\%. IR $\left(\mathrm{KBr}, \mathrm{cm}^{-1}\right)$ : $3430\left(\nu_{\mathrm{H}_{2} \mathrm{O}}\right) ; 3305$ and $3218\left(\nu_{\mathrm{NH} / \mathrm{NH}}\right) ; 1638\left(\nu_{\mathrm{C}=\mathrm{O}}\right) ; 1555\left(\nu_{\mathrm{C}=\mathrm{N}}\right)$; 1478,1063 and $621\left(\nu_{\text {Pyridine ring }}\right) ; 477\left(\nu_{\mathrm{M}-\mathrm{O}}\right) ; 450\left(\nu_{\mathrm{M}-\mathrm{N}}\right)$. $(\mathrm{FAB}+) \mathrm{MS}: \mathrm{M}^{\bullet+}$ 955, 957, $959(10 \%, 6 \%, 3 \%) ; m / z$ 937, 939, 941 (25\%, 50\%, 70\%); 498, 500 (50\%, 30\%); 244 (18\%). Uv-Vis $\left(\mathrm{cm}^{-1}\right): \nu_{1}, 9680 ; v_{2}, 15604 ; v_{3}, 25634$.

\subsubsection{Zn(II) Complex of Schiff Base HL}

Light Yellow Solid. Yield: 69\%; m.p. > 340 C; Anal. Calcd. for $\left[\mathrm{Zn}\left(\mathrm{C}_{25} \mathrm{H}_{16} \mathrm{O}_{2} \mathrm{~N}_{4} \mathrm{Cl}\right)(\mathrm{Cl})\right] \mathrm{H}_{2} \mathrm{O}(\mathrm{Mr}=557.40)$ : C, 53.72; $\mathrm{H}$, 3.22 ; N, 10.02\%. Found: C, 53.99; H, 3.35; N, 10.19\%. IR (KBr, $\left.\mathrm{cm}^{-1}\right)$ : $3420\left(\nu_{\mathrm{H}_{2} \mathrm{O}}\right) ; 3305$ and $3218\left(\nu_{\mathrm{NH} / \mathrm{NH}}\right) ; 1634\left(\nu_{\mathrm{C}=\mathrm{O}}\right)$; $1557\left(\nu_{\mathrm{C}=\mathrm{N}}\right) ; 1489,1066$ and $615\left(\nu_{\text {Pyridine ring }}\right) ; 470\left(\nu_{\mathrm{M}-\mathrm{O}}\right) ; 425$ $\left(\nu_{\mathrm{M}-\mathrm{N}}\right) ; 357\left(\nu_{\mathrm{M}-\mathrm{Cl}}\right) .{ }^{1} \mathrm{H}$ NMR (DMSO- $\left.d_{6}\right): \delta 13.12(\mathrm{~s}, 1 \mathrm{H}$, CONH); 11.53 (s, 1H, indole NH); 8.45 (s, 1H, HC=N); 7.358.55 (m, 12H, ArH). (FAB+) MS: $\mathrm{M}^{\bullet+} 557,559,561$ (10\%, 18\%, $15 \%) ; m / z 539,541$, and 543 (48\%, 72\%, 20\%); 469 (48\%); 250 $(60 \%)$.

\subsubsection{Cd(II) Complex of Schiff Base HL}

Pale Yellow Solid. Yield: 71\%; m.p. > $340^{\circ} \mathrm{C}$; Anal. Calcd. for $\left[\mathrm{Cd}\left(\mathrm{C}_{25} \mathrm{H}_{16} \mathrm{O}_{2} \mathrm{~N}_{4} \mathrm{Cl}\right)(\mathrm{Cl})\right] \mathrm{H}_{2} \mathrm{O}(\mathrm{Mr}=604.41): \mathrm{C}, 49.55 ; \mathrm{H}$, 2.97; N, 9.24\%. Found: C, 49.71; H, 2.81; N, 9.35\%. IR (KBr, $\left.\mathrm{cm}^{-1}\right)$ : $3423\left(\nu_{\mathrm{H}_{2} \mathrm{O}}\right) ; 3293$ and $3221\left(\nu_{\mathrm{NH} / \mathrm{NH}}\right) ; 1637\left(\nu_{\mathrm{C}=\mathrm{O}}\right)$; $1550\left(\nu_{\mathrm{C}=\mathrm{N}}\right) ; 1425,1059$, and $699\left(\nu_{\text {Pyridine ring }}\right) ; 469\left(\nu_{\mathrm{M}-\mathrm{O}}\right)$; $419\left(v_{\mathrm{M}-\mathrm{N}}\right) ; 350\left(\nu_{\mathrm{M}-\mathrm{Cl}}\right) .{ }^{1} \mathrm{H}$ NMR (DMSO- $\left.d_{6}\right): \delta 13.14(\mathrm{~s}, 1 \mathrm{H}$, $\mathrm{CONH}) ; 11.62$ (s, $1 \mathrm{H}$, indole $\mathrm{NH}) ; 8.46$ (s, 1H, HC=N); 7.208.35 (m, 12H, ArH).

\subsection{6. $H g(I I)$ Complex of Schiff Base $H L$}

Light Yellow Solid. Yield: 68\%; m.p. $330^{\circ} \mathrm{C}$; Anal. Calcd. for $\left[\mathrm{Hg}\left(\mathrm{C}_{25} \mathrm{H}_{16} \mathrm{O}_{2} \mathrm{~N}_{4} \mathrm{Cl}\right)(\mathrm{Cl})\right](\mathrm{Mr}=674.59): \mathrm{C}, 44.40 ; \mathrm{H}, 2.36$; $\mathrm{N}, 8.28 \%$. Found: C, 44.61; H, 2.42; N, 8.36\%. IR $\left(\mathrm{KBr}, \mathrm{cm}^{-1}\right)$ : 3295 and $3230\left(\nu_{\mathrm{NH} / \mathrm{NH}}\right) ; 1664\left(\nu_{\mathrm{C}=\mathrm{O}}\right) ; 1560\left(\nu_{\mathrm{C}=\mathrm{N}}\right) ; 1420,1060$, and $640\left(\nu_{\text {Pyridine ring }}\right) ; 550\left(\nu_{\mathrm{M}-\mathrm{O}}\right) ; 428\left(\nu_{\mathrm{M}-\mathrm{N}}\right) ; 352\left(\nu_{\mathrm{M}-\mathrm{Cl}}\right)$.

\subsection{Pharmacology}

2.5.1. Antimicrobial Assays. The biological activities of the synthesized Schiff base HL and its $\mathrm{Cu}(\mathrm{II}), \mathrm{Co}(\mathrm{II}), \mathrm{Ni}(\mathrm{II})$, $\mathrm{Zn}(\mathrm{II}), \mathrm{Cd}(\mathrm{II})$, and $\mathrm{Hg}(\mathrm{II})$ complexes were studied for their antibacterial and antifungal activities by the disc and well diffusion method, respectively. The in vitro antibacterial activities of the compounds were tested against two Gramnegative Escherichia coli (MTCC 46) and Salmonella typhi (MTCC 98) and two Gram-positive Bacillus subtilis (MTCC 736) and Staphylococcus aureus (MTCC 3160) bacteria.
The in vitro antifungal activities were carried out against Candida albicans (MTCC 227), Cladosporium oxysporum (MTCC 1777), and Aspergillus niger (MTCC 1881) fungi [31, 32]. The stock solutions of the test chemicals $\left(1 \mathrm{mg} \mathrm{mL}^{-1}\right)$ were prepared by dissolving $10 \mathrm{mg}$ of the each test compound in $10 \mathrm{~mL}$ of distilled DMSO solvent. The different concentrations of the test compounds $\left(100,75,50,25\right.$, and $\left.12.5 \mu \mathrm{g} \mathrm{mL}^{-1}\right)$ were prepared by diluting the stock solution with the required amount of freshly distilled DMSO. Further the controlled experiments were carried out by using freshly distilled DMSO solvent alone.

2.5.2. Antibacterial Screening. Muller-Hinton agar media was used for the antibacterial studies. The pure dehydrated Muller-Hilton agar (38 g) was dissolved in $1000 \mathrm{~mL}$ distilled water. The pure cultures of the bacterial strains E. coli, $S$. aureus, B. subtilis, and S. typhi were subcultured by inoculating in the nutrient broth, and they were incubated at $37^{\circ} \mathrm{C}$ for about $18 \mathrm{~h}$. The agar plates were prepared by using the above Muller-Hinton agar media, and wells were dug with the help of $6 \mathrm{~mm}$ sterile metallic cork borer. Each plate was inoculated with 18 -h-old bacterial culture $(100 \mu \mathrm{L})$ using a micropipette and spreaded uniformly using bent glass rod on each plate. The drug gentamycin is used as standard. Different concentration of the test compounds were incorporated into the wells using micropipette, and the plates were kept for incubation at $37^{\circ} \mathrm{C}$ for $24 \mathrm{~h}$. Soon after the completion of incubation period, the diameter of the inhibition zone generated by each test compound against bacterial growth was measured using antibiogram zone measuring scale.

2.5.3. Antifungal Screening. Potato dextrose agar (PDA) media was used for the antifungal studies. The following ingredients were used to prepare the media: potatoes (sliced washed unpeeled) $200 \mathrm{~g}$, dextrose $20 \mathrm{~g}$, and agar $20 \mathrm{~g}$ in $1000 \mathrm{~mL}$ distilled water. The pure cultures C. albicans, $C$. oxysporum, and $A$. niger were inoculated on PDA slants. These slants were incubated at $32^{\circ} \mathrm{C}$ for 7 days. To these 7-day-old slants of fungal strains, $10 \mathrm{~mL}$ of $0.1 \%$ tween- 80 solution was added, and the culture were scraped with sterile inoculating loop to get uniform spore suspension. The agar plates were prepared by using the above potato dextrose agar media and wells were dug with the help of $6 \mathrm{~mm}$ sterile metallic cork borer. Each plate was inoculated with 7-dayold spore suspension of each fungal culture $(100 \mu \mathrm{L})$ using a micropipette and spreaded uniformly using bent glass rod on each plate. Then each well was incorporated with the test compound solution of different concentrations. The drug fluconazole is used as standard. All the inoculated plates were incubated at $32^{\circ} \mathrm{C}$ for about $48 \mathrm{~h}$. Soon after the completion of incubation period the diameter of the inhibition zone generated by each test compound against fungal growth was measured using antibiogram zone measuring scale.

2.5.4. DNA Cleavage Experiment. The extent to which the newly synthesized ligands and their metal complexes could function as DNA cleavage agents was examined using $E$. coli DNA as a target. The electrophoresis method was employed 
TABLE 2: The IR data of ligand HL and its complexes $\left(\mathrm{cm}^{-1}\right)$.

\begin{tabular}{|c|c|c|c|c|c|c|c|c|}
\hline Compounds & $\nu_{\mathrm{NH} / \mathrm{NH}}$ & $\nu_{\mathrm{C}=\mathrm{O}}$ & $v_{\mathrm{H}_{2} \mathrm{O}}$ & $\nu_{\mathrm{C}=\mathrm{N}}$ & Pyridine ring & $\nu_{\mathrm{M}-\mathrm{O}}$ & $v_{\mathrm{M}-\mathrm{N}}$ & $v_{\mathrm{M}-\mathrm{Cl}}$ \\
\hline HL & $3311,3229,3162$ & 1674,1661 & - & 1608 & - & - & - & - \\
\hline $\mathrm{Cu}$ complex & 3283,3221 & $1639,-$ & 3418 & 1548 & $1493,1077,615$ & 514 & 442 & - \\
\hline Co complex & 3271,3230 & $1629,-$ & 3423 & 1551 & $1489,1061,670$ & 553 & 435 & - \\
\hline Ni complex & 3305,3218 & $1638,-$ & 3430 & 1555 & $1478,1063,621$ & 477 & 450 & - \\
\hline Zn complex & 3305,3218 & $1634,-$ & 3420 & 1557 & $1489,1066,615$ & 470 & 425 & 357 \\
\hline Cd complex & 3293,3221 & $1637,-$ & 3423 & 1550 & $1425,1059,699$ & 469 & 419 & 350 \\
\hline Hg complex & 3295,3230 & $1664,-$ & - & 1560 & $1420,1060,640$ & 550 & 428 & 352 \\
\hline
\end{tabular}

$\mathrm{HL}=$ ligand.

to study the efficiency of cleavage by the synthesized compounds. Nutrient broth media was used (Peptone $10 \mathrm{~g}, \mathrm{NaCl}$ $10 \mathrm{~g}$ and yeast extract $5 \mathrm{gL}^{-1}$ ) for culturing E. coli. The electrophoresis of the test compounds was done according to the literature method [33].

The freshly prepared $E$. coli culture $(1.5 \mathrm{~mL})$ is centrifuged, and the pellets obtained, which was then dissolved in $0.5 \mathrm{~mL}$ of lysis buffer (50 mM EDTA, $100 \mathrm{mM}$ tris $\mathrm{pH} 8.0,50 \mathrm{mM}$ lysozyme). To this, $0.5 \mathrm{~mL}$ of saturated phenol was added and incubated at $55^{\circ} \mathrm{C}$ for $10 \mathrm{~min}$. Soon after the incubation the solution was centrifuged at 10,000 rpm for $10 \mathrm{~min}$, and to the supernatant liquid, equal volume of chloroform: isoamyl alcohol $(24: 1)$ and $1 / 20$ th volume of $3 \mathrm{M}$ sodium acetate $(\mathrm{pH} 4.8)$ were added. Again the solution is centrifuged at $10,000 \mathrm{rpm}$ for $10 \mathrm{~min}$ and the supernatant layer collected is then mixed with 3 volumes of chilled absolute alcohol, and the DNA precipitates. The precipitated DNA was separated by centrifugation, and the pellet was dried and dissolved in Tris buffer (10 mM tris $\mathrm{pH}$ 8.0) and stored in cold condition.

Agarose $(250 \mathrm{mg}$ ) was dissolved in hot tris-acetateEDTA (TAE) buffer (25 mL) (4.84 g Tris base, $\mathrm{pH}-8.0,0.5 \mathrm{M}$ EDTA L ${ }^{-1}$ ), and heated to boil for few minutes. When the gel attains approximately $55^{\circ} \mathrm{C}$, it was then poured into the gas cassette fitted with comb. Slowly the gel was allowed to solidify by cooling to room temperature and then carefully the comb was removed. The solidified gel was placed in the electrophoresis chamber containing TAE buffer. Test compounds $\left(1 \mathrm{mg} \mathrm{mL}^{-1}\right)$ were prepared in DMSO. The test compounds $(25 \mu \mathrm{g})$ were added to the isolated DNA of $E$. coli, and they were incubated for $2 \mathrm{~h}$ at $37^{\circ} \mathrm{C}$. Soon after the incubation period the DNA sample $(20 \mu \mathrm{L})$ mixed with bromophenol blue dye in equimolar ratio along with standard DNA marker containing TAE buffer was loaded carefully into the wells, and the constant $50 \mathrm{~V}$ of electricity was supplied for about $30 \mathrm{~min}$. Later, the gel was removed, and it was stained with ethidium bromide solution $\left(10 \mu \mathrm{g} \mathrm{mL}^{-1}\right)$ for $15-20 \mathrm{~min}$, then the bands were observed and photographed under UVilluminator.

2.5.5. Antioxidant Assay (Free Radical Scavenging Activity). The free radical scavenging activity of the test samples was determined with the 2,2-diphenyl-1-picryl-hydrazyl (DPPH) method [34]. Different concentrations of test compounds $(10 \mu \mathrm{g}, 50 \mu \mathrm{g}$, and $100 \mu \mathrm{g})$ and standard butylated hydroxy anisole (BHA) were taken in different test tubes, and the volume of each test tube was adjusted to $100 \mu \mathrm{L}$ by adding distilled DMF. To the sample solution in DMF, $5 \mathrm{~mL}$ methanolic solution of DPPH $(0.1 \mathrm{mM})$ was added to these tubes. The tubes were allowed to stand for $30 \mathrm{~min}$. The control experiment was carried out as above without the test samples. The absorbance of test solutions was measured at $517 \mathrm{~nm}$. The reduction of DPPH was calculated relative to the measured absorbance of the control. Radical scavenging activity was calculated using the following formula:

$\%$ Radical scavenging activity

$=\left[\frac{\text { Control optical density }- \text { Sample optical density }}{\text { Control optical density }}\right] \times 100$.

\section{Results and Discussion}

All the synthesized metal complexes are coloured solids, amorphous in nature, and stable in air. Melting points of the newly synthesized metal complex were above $>300^{\circ} \mathrm{C}$. The complexes are insoluble in water and common organic solvents but are soluble in solvents like DMF and DMSO. Elemental analysis and analytical data of the complexes suggest that the metal to ligand ratio of the complexes is $1: 2$ stoichiometry of the type $\left[\mathrm{M}(\mathrm{L})_{2}\right] \mathrm{H}_{2} \mathrm{O}$ for $\mathrm{Cu}(\mathrm{II})$, $\mathrm{Co}(\mathrm{II})$, and $\mathrm{Ni}$ (II) complexes, $1: 1$ stoichiometry of the type $[\mathrm{M}(\mathrm{L})(\mathrm{Cl})] \mathrm{H}_{2} \mathrm{O}$ for $\mathrm{Zn}(\mathrm{II})$ and $\mathrm{Cd}(\mathrm{II})$ complexes and $[\mathrm{M}(\mathrm{L})(\mathrm{Cl})]$ for $\mathrm{Hg}(\mathrm{II})$ complex, respectively, where L stands for deprotonated ligand. The molar conductance values are too low to account for any dissociation of the complexes in DMF (24-60 $\mathrm{ohm}^{-1} \mathrm{~cm}^{2}$ mole $\mathrm{C}^{-1}$ ), indicating their nonelectrolytic nature of the complexes in DMF (Table 1) [35].

3.1. IR Spectral Studies. The important IR bands of the Schiff base HL and its metal complexes are represented in Table 2. IR spectrum of Schiff base HL displayed one sharp band at 3311 and two weak bands at 3229 and $3162 \mathrm{~cm}^{-1}$ due to indole $\mathrm{NH}$ and two $\mathrm{NH} / \mathrm{NH}$ functions of two amide groups, respectively. Two sharp peaks observed at 1674 and $1661 \mathrm{~cm}^{-1}$ are due to two carbonyl groups of two $\mathrm{CONH}$ functions. A band at $1608 \mathrm{~cm}^{-1}$ is due to $\mathrm{C}=\mathrm{N}$ of azomethine group of the Schiff base. Disappearance of band at $1674 \mathrm{~cm}^{-1}$ due to quinolinone carbonyl function with the appearance of a new band in the region $1290-1287 \mathrm{~cm}^{-1}$ in all the 
TABle 3: The ${ }^{1} \mathrm{H}$ NMR data of ligand $\mathbf{H L}$ and its $\mathrm{Zn}(\mathrm{II})$ and $\mathrm{Cd}(\mathrm{II})$ complexes.

\begin{tabular}{lc}
\hline Ligand/complexes & ${ }^{1} \mathrm{H}$ NMR data $(\delta)$ \\
\hline HL & 12.20 and $12.00(\mathrm{~s}, 2 \mathrm{H}$, two CONH $), 11.60(\mathrm{~s}, 1 \mathrm{H}$, indole $\mathrm{NH}), 8.40(\mathrm{~s}, 1 \mathrm{H}, \mathrm{HC}=\mathrm{N}), 7.10-8.20(\mathrm{~m}, 13 \mathrm{H}, \mathrm{ArH})$. \\
Zn complex & $13.12(\mathrm{~s}, 1 \mathrm{H}, \mathrm{CONH}), 11.53(\mathrm{~s}, 1 \mathrm{H}$, indole NH$), 8.45(\mathrm{~s}, 1 \mathrm{H}, \mathrm{HC}=\mathrm{N}), 7.35-8.55(\mathrm{~m}, 12 \mathrm{H}, \mathrm{ArH})$. \\
Cd complex & $13.14(\mathrm{~s}, 1 \mathrm{H}, \mathrm{CONH}), 11.62(\mathrm{~s}, 1 \mathrm{H}$, indole NH$), 8.46(\mathrm{~s}, 1 \mathrm{H}, \mathrm{HC}=\mathrm{N}), 7.20-8.35(\mathrm{~m}, 12 \mathrm{H}, \mathrm{ArH})$. \\
\hline
\end{tabular}

$\mathbf{H L}=$ ligand.

complexes proves the enolization of quinolinone carbonyl during complexation and formation of a new bond between enolized oxygen and metal ion via deprotonation. The shift of band due to amide carbonyl attached to 2-position of indole from $1661 \mathrm{~cm}^{-1}$ to $1639-1629 \mathrm{~cm}^{-1}$ in case of all the complexes confirms the coordination of metal ion with oxygen atom of this carbonyl function without undergoing enolization [36]. The bands appeared at $3305-3283$ and $3230-3218 \mathrm{~cm}^{-1}$ due to indole $\mathrm{NH}$ and $\mathrm{NH}$ of amide function attached to 2position of indole, respectively, in case of complexes it proves the noninvolvement of these $\mathrm{NH}$ functions in complexation, since these two peaks have appeared at 3311 and $3229 \mathrm{~cm}^{-1}$ in case of Schiff base HL. Absorption frequency of $\mathrm{HC}=\mathrm{N}$ function which has appeared at $1608 \mathrm{~cm}^{-1}$ in the Schiff base has been shifted towards lower frequency by $60-48 \mathrm{~cm}^{-1}$ and appeared in the region $1568-1548 \mathrm{~cm}^{-1}$ in all the complexes which indicates the coordination of metal ion with azomethine nitrogen atom [37]. This is further confirmed by the appearance of new bands in the region $555-469 \mathrm{~cm}^{-1}$ and $470-419 \mathrm{~cm}^{-1}$ in all the complexes which are due to $v_{\mathrm{M}-\mathrm{O}}$ and $v_{\mathrm{M}-\mathrm{N}}$ stretching vibrations, respectively [38]. In $\mathrm{Zn}(\mathrm{II}), \mathrm{Cd}(\mathrm{II})$, and $\mathrm{Hg}(\mathrm{II})$ complexes of ligand $\mathbf{H L}$, new bands observed in the region $357-350 \mathrm{~cm}^{-1}$ are due to $\nu_{\mathrm{M}-\mathrm{Cl}}$ vibrations.

Bands observed in the region 1493-1420, 1077-1059, and $699-615 \mathrm{~cm}^{-1}$ in all the complexes are due to pyridine ring vibration of quinoline moiety. The broad band observed in all the complexes except $\mathrm{Hg}$ (II) complex of ligand $\mathrm{HL}$ in the region $3430-3418 \mathrm{~cm}^{-1}$ is assigned to $\nu_{\mathrm{OH}}$ vibration of the lattice water molecules [39].

3.2. ${ }^{1} H$ NMR Spectral Studies. The ${ }^{1} \mathrm{H}$ NMR data of Schiff base $\mathrm{HL}$ and its $\mathrm{Zn}$ (II) and Cd(II) complexes are presented in Table 3. The ${ }^{1} \mathrm{H}$ NMR spectrum of Schiff base HL displayed three broad singlets at $12.20,12.00$, and $11.60 \mathrm{ppm}$ which are due to proton of two amide functions $(\mathrm{s}, 2 \mathrm{H}, \mathrm{CONH})$ and proton of indole $\mathrm{NH}(\mathrm{s}, 1 \mathrm{H}, \mathrm{NH})$, respectively. The signals due to proton of azomethine function and thirteen aromatic protons have appeared at $8.40 \mathrm{ppm}(\mathrm{s}, 1 \mathrm{H}, \mathrm{HC}=\mathrm{N})$ and $7.10-$ $8.20 \mathrm{ppm}(\mathrm{m}, 13 \mathrm{H}, \mathrm{ArH})$, respectively.

In the spectra of $\mathrm{Zn}(\mathrm{II})$ and $\mathrm{Cd}(\mathrm{II})$ complexes displayed two peaks at $13.12,11.53 \mathrm{ppm}$ and $13.14,11.62 \mathrm{ppm}$ due to proton of an amide function and proton of indole $\mathrm{NH}$, respectively. The disappearance of the signal at $12.00 \mathrm{ppm}$ which was there in the spectrum of Schiff base HL confirms the enolization of CONH function of quinolinone moiety and its involvement in complexation with metal ion through oxygen atom of enolized carbonyl function via deprotonation. The signal due to azomethine proton in $\mathrm{Zn}$ (II) and $\mathrm{Cd}$ (II) complexes have been shifted towards lower field strength when compared to the spectra of ligand; they have appeared at 8.45 and $8.46 \mathrm{ppm}$, respectively. The aromatic protons in case of $\mathrm{Zn}$ (II) and Cd(II) complex have been resonated in the region $7.35-8.55$ and $7.20-8.35 \mathrm{ppm}$, respectively. The shift of the entire proton towards lower field strength when compared to Schiff base $\mathbf{H L}$ proves beyond doubt the formation of complex with metal ion.

3.3. FAB-Mass Spectral Studies. The representative $\mathrm{Ni}(\mathrm{II})$ and $\mathrm{Zn}(\mathrm{II})$ complexes have been subjected for their mass spectral studies. The FAB-mass spectrum of $\mathrm{Ni}$ (II) complex is depicted in Figure 1, shows a molecular ion peak at $\mathrm{M}^{\circ+}$ 955,957 , and $959(2 \%, 6 \%, 18 \%)$ which corresponds to its molecular weight, confirming the stoichiometry ratio of metal chelates as $\left[\mathrm{M}(\mathrm{L})_{2}\right] \mathrm{H}_{2} \mathrm{O}$. Further fragment ion observed at $m / z 937,939,941(25 \%, 50 \%, 70 \%), 498,500(50 \%$, $30 \%)$, and $244(20 \%)$ are due to the sequential expulsion of $\mathrm{H}_{2} \mathrm{O}, \mathrm{C}_{25} \mathrm{H}_{16} \mathrm{~N}_{3} \mathrm{O}_{2} \mathrm{Cl}$, and $\mathrm{C}_{15} \mathrm{H}_{9} \mathrm{NOCl}$ species, respectively, from the molecular ion. This fragmentation pattern is in consistency with its structure (Scheme 2).

The FAB-mass spectrum of $\mathrm{Zn}$ (II) complex (Figure 2) shows a molecular ion peak $\mathrm{M}^{\circ+} 557,559$, and $561(10 \%, 18 \%$, $14 \%$ ) which corresponds to its molecular weight, confirming the stoichiometry ratio of metal chelates as $[\mathrm{M}(\mathrm{L})(\mathrm{Cl})] \mathrm{H}_{2} \mathrm{O}$. Further fragment ion observed at $m / z 539,541,543(48 \%$, $72 \%, 20 \%), 469(48 \%)$, and $250(58 \%)$ are due to the sequential expulsion of $\mathrm{H}_{2} \mathrm{O}, 2 \mathrm{Cl}$, and $\mathrm{C}_{15} \mathrm{H}_{9} \mathrm{NO}$ species, respectively, from the molecular ion. This fragmentation pattern (Scheme 3 ) is in conformity with the structure.

3.4. Electronic Spectral Studies. Electronic spectral data of the $\mathrm{Cu}(\mathrm{II}), \mathrm{Co}(\mathrm{II})$, and $\mathrm{Ni}(\mathrm{II})$ complexes of the Schiff base $\mathrm{HL}$ are given in Table 4. Electronic spectral studies of all these complexes were carried out in DMF at $10^{-3} \mathrm{M}$ concentration. The green coloured $\mathrm{Cu}(\mathrm{II})$ complex displayed low intensity single broad band in the region $13769-17463 \mathrm{~cm}^{-1}$. The broadness of the band is assigned due to ${ }^{2} \mathrm{~B}_{1 \mathrm{~g}} \rightarrow{ }^{2} \mathrm{Eg}$, ${ }^{2} \mathrm{~B}_{1 \mathrm{~g}} \rightarrow{ }^{2} \mathrm{~B}_{2 \mathrm{~g}}$ and ${ }^{2} \mathrm{~B}_{1 \mathrm{~g}} \rightarrow{ }^{2} \mathrm{~A}_{\mathrm{tg}}$ transitions, which are similar in energy and give rise to only one broad absorption band, and the broadness of the band is due to dynamic Jahn-Teller distortion. These data suggest that the $\mathrm{Cu}(\mathrm{II})$ complex have distorted octahedral geometry [40].

The electronic spectra of brown coloured Co(II) complex shows two absorption bands observed at $15977 \mathrm{~cm}^{-1}$ and $19518 \mathrm{~cm}^{-1}$ due to the ${ }^{4} \mathrm{~T}_{1 \mathrm{~g}}(\mathrm{~F}) \rightarrow{ }^{4} \mathrm{~A}_{2 \mathrm{~g}}(\mathrm{~F})\left(\nu_{2}\right)$ and ${ }^{4} \mathrm{~T}_{1 \mathrm{~g}}(\mathrm{~F}) \rightarrow{ }^{4} \mathrm{~T}_{2 \mathrm{~g}}(\mathrm{P})\left(\nu_{3}\right)$ transitions, respectively, which are 


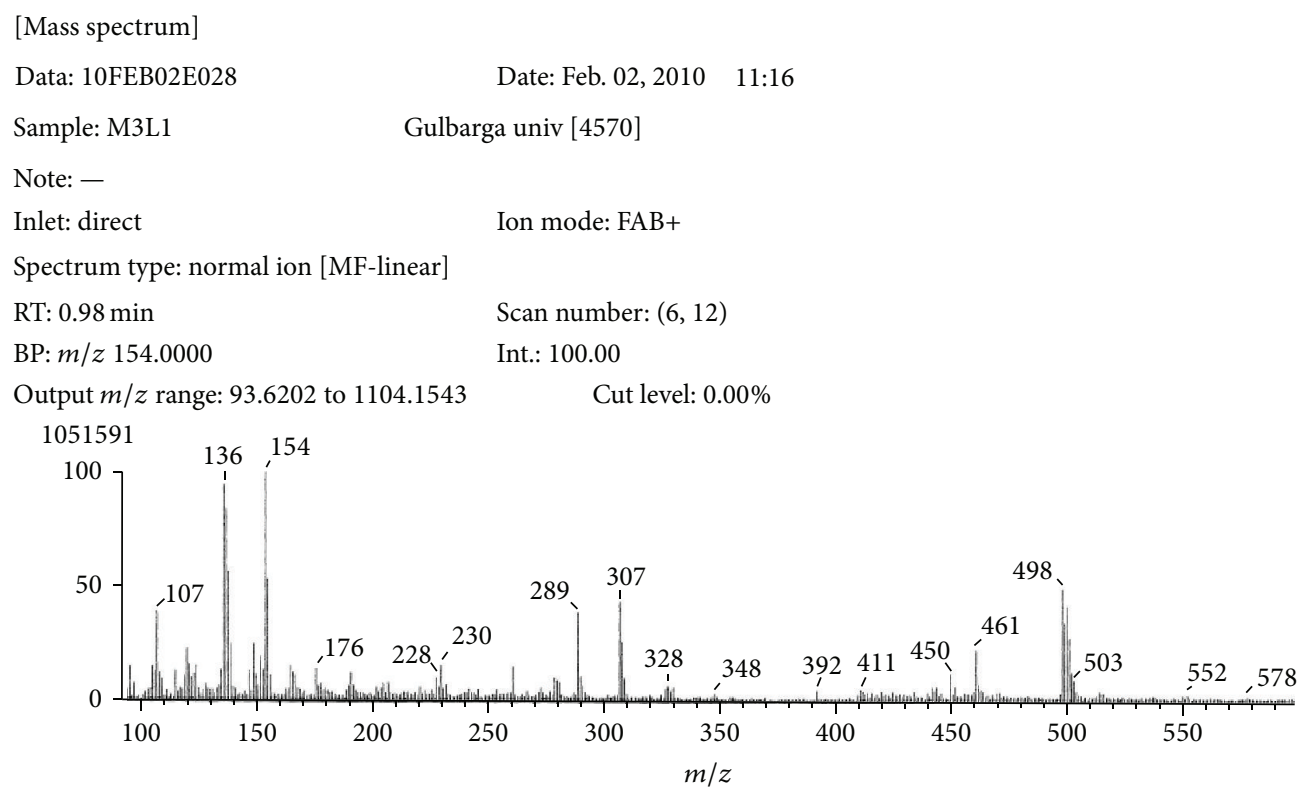

(a)

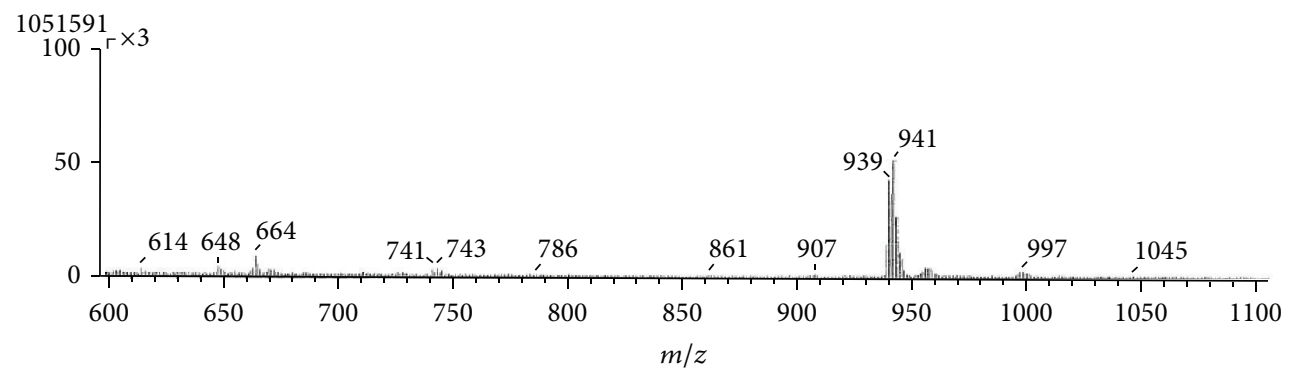

(b)

FIGURE 1: FAB-mass spectrum of $\mathrm{Ni}(\mathrm{II})$ complex.

TABLE 4: Electronic spectral bands and ligand field parameters of the Co(II), Ni(II), and Cu(II) complexes in DMF (10 $\left.{ }^{-3} \mathrm{M}\right)$ solution.

\begin{tabular}{|c|c|c|c|c|c|c|c|c|c|}
\hline \multirow{2}{*}{ Complexes } & \multicolumn{3}{|c|}{ Transitions in $\mathrm{cm}^{-1}$} & \multirow{2}{*}{$\mathrm{Dq}\left(\mathrm{cm}^{-1}\right)$} & \multirow{2}{*}{$B^{\prime}\left(\mathrm{cm}^{-1}\right)$} & \multirow{2}{*}{$\beta$} & \multirow{2}{*}{$\beta \%$} & \multirow{2}{*}{$v_{2} / v_{1}$} & \multirow{2}{*}{ LFSE ( $\mathrm{kcal})$} \\
\hline & $v_{1}{ }^{*}$ & $v_{2}$ & $v_{3}$ & & & & & & \\
\hline $\mathrm{Cu}(\mathrm{II})$ complex & & $13769-1746$ & & 1530 & - & - & - & - & 26.22 \\
\hline $\mathrm{Co}(\mathrm{II})$ complex & 7447 & 15977 & 19518 & 853 & 877 & 0.843 & 9.680 & 1.480 & 14.622 \\
\hline $\mathrm{Ni}(\mathrm{II})$ complex & 9680 & 15604 & 25634 & 968 & 812 & 0.780 & 21.92 & 1.470 & 33.188 \\
\hline
\end{tabular}

${ }^{*}$ Calculated values.

in good agreement with the reported values [41]. The lowest band, $v_{1}$ is not to be observed due to the limited range of the instrument used but could be calculated using the band fitting procedure suggested by Underhill and Billing [42]. These transitions suggest octahedral geometry for the Co(II) complex.

The brown $\mathrm{Ni}(\mathrm{II})$ complex under present investigation exhibited two bands in the region $15604 \mathrm{~cm}^{-1}$ and $25634 \mathrm{~cm}^{-1}$. These bands are assigned to ${ }^{3} \mathrm{~A}_{2 \mathrm{~g}}(\mathrm{~F}) \rightarrow$ ${ }^{3} \mathrm{~T}_{1 \mathrm{~g}}(\mathrm{~F})\left(v_{2}\right)$ and ${ }^{3} \mathrm{~A}_{2 \mathrm{~g}}(\mathrm{~F}) \rightarrow{ }^{3} \mathrm{~T}_{1 \mathrm{~g}}(\mathrm{P})\left(v_{3}\right)$ transitions, respectively, in an octahedral environment. The band $v_{1}$ was calculated by using a band fitting procedure [42].
The octahedral geometry was further supported by the values of ligand field parameters, such as the Racah interelectronic repulsion parameter $\left(B^{\prime}\right)$, ligand field splitting energy $(10 \mathrm{Dq})$, nephelauxetic parameter $(\beta)$, and ligand field stabilization energy (LFSE) [43]. The calculated $B^{\prime}$ values for the $\mathrm{Co}(\mathrm{II})$ and $\mathrm{Ni}(\mathrm{II})$ complexes were lower than the free ion values, which is due to the orbital overlap and delocalisation of $\mathrm{d}$-orbitals. The $\beta$ values are important in determining the covalency for the metal-ligand bond, and they were found to be less than unity, suggesting a considerable amount of covalency for the metal-ligand bonds. The $\beta$ value for the $\mathrm{Ni}$ (II) complex was less than that of the Co(II) complex, indicating the greater covalency of the M-L bond [44] 
[Mass spectrum]

Data: 10FEB02E028

Sample: M5L

Note:

Inlet: direct

Spectrum type: normal ion [MF-linear]

RT: $0.00 \mathrm{~min}$

BP: $m / z 154.0000$

Output $m / z$ range: 79.0801 to 584.3472

684817

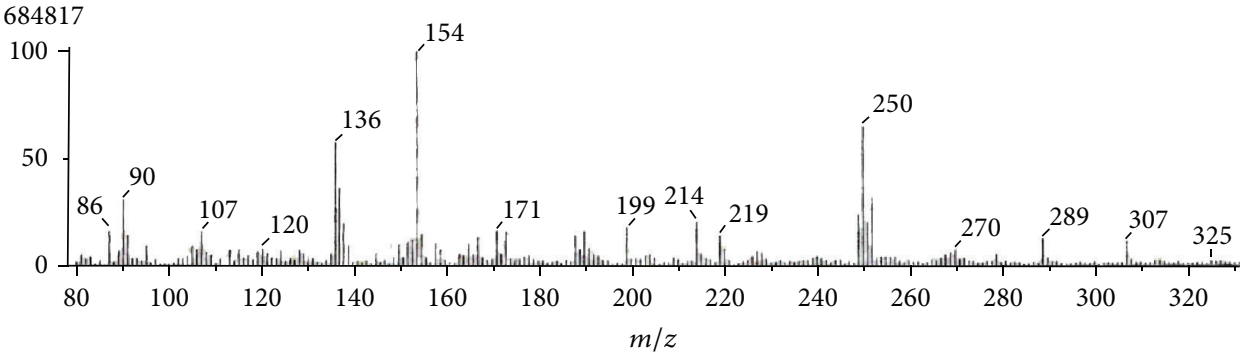

(a)

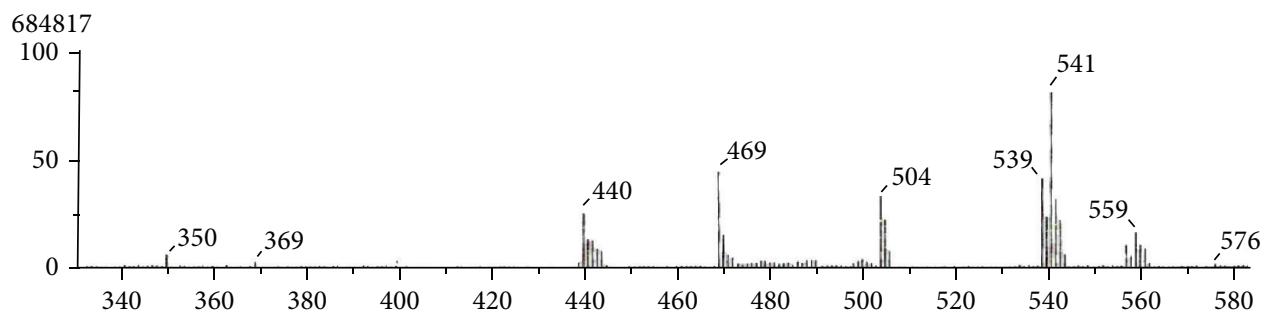

(b)
Date: Feb. 02, 2010

Gulbarga number 827

Ion mode: $\mathrm{FAB}+$

Scan number: $(1,2)$

Int.: 64.20

Cut level: $0.00 \%$

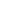

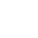




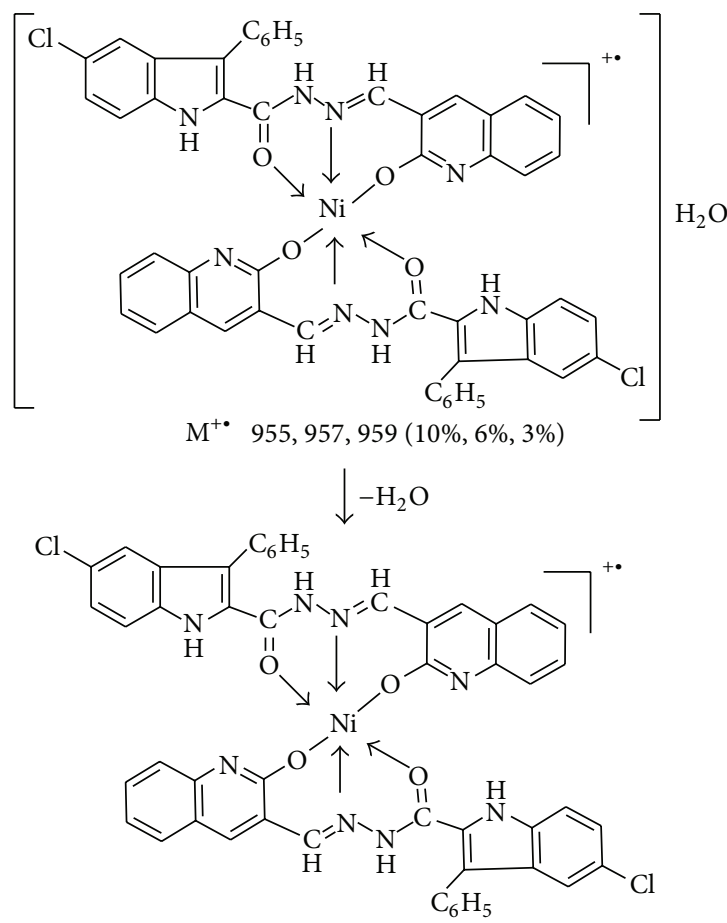

$m / z 937,939,941(25 \%, 50 \%, 70 \%)$<smiles></smiles>

$m / z 498,500(50 \%, 38 \%)$<smiles>CC(C)(C)c1nc2ccccc2cc1C=N[NH+]1CCCCC1</smiles>

SCHeme 2: Mass fragmentation of $\mathrm{Ni}(\mathrm{II})$ complex.

indicating that the exchange coupling effects are not operative in the present complex.

3.7. Thermal Studies. The thermal stabilities of the complexes have been studied as a function of temperature. The proposed thermal decomposition pattern with temperature and the percentage of metal oxide obtained are depicted in Table 5.

The Thermo gravimetric curve (TGA) of the representative $\mathrm{Cu}(\mathrm{II})$ complex is shown in Figure 3, showing three decomposition steps. The first decomposition occurs at a temperature of $100^{\circ} \mathrm{C}$ which is due to the loss of a lattice water molecule, the second decomposition occurs at a temperature of $335^{\circ} \mathrm{C}$ which corresponds to loss of two $\mathrm{C}_{15} \mathrm{H}_{10} \mathrm{~N}_{3} \mathrm{OCl}$<smiles>CCCCCc1c(C(=O)NN=Cc2cc3ccccc3nc2O[Y12](Cl)(Cl)CCCCC)[nH]c2ccc(Cl)cc12</smiles>

$\mathrm{M}^{+\bullet} 557,559,561(10 \%, 18 \%, 15 \%)$

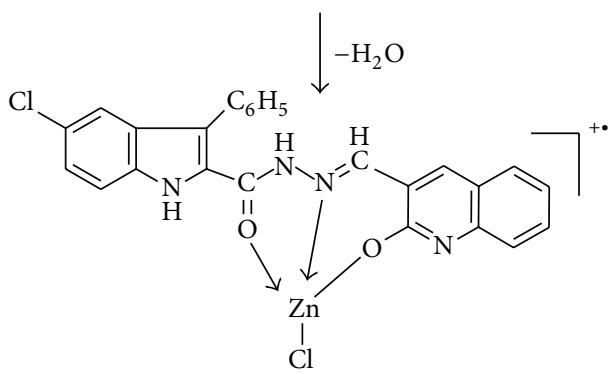

$m / z, 539,541,543(48 \%, 72 \%, 20 \%)$

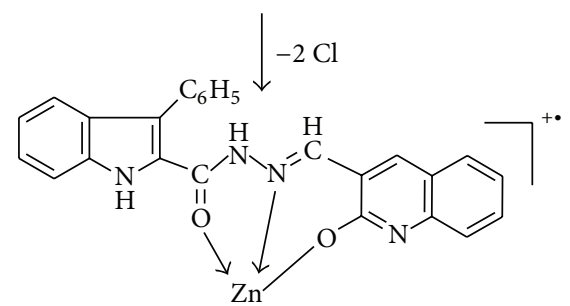
$m / z, 469(48 \%)$<smiles>O=Cc1[nH]c2ccccc2c1-c1ccccc1</smiles><smiles>C[13CH2]N/N=C/c1cc2ccccc2nc1O</smiles>

Scheme 3: Mass fragmentation of $\mathrm{Zn}(\mathrm{II})$ complex.

species, and the third decomposition occurs at a temperature of $519^{\circ} \mathrm{C}$ due to the loss of two $\mathrm{C}_{4} \mathrm{H}_{4}$ species. Further the complex underwent decomposition in a gradual manner rather than with the sharp decomposition up to $750^{\circ} \mathrm{C}$ corresponds to loss of remaining organic moiety, leaving behind the residue copper oxide.

The thermal decomposition pattern of $\mathrm{Co}(\mathrm{II}), \mathrm{Zn}$ (II), and $\mathrm{Hg}$ (II) complexes shows two decomposition steps each. The first decomposition occurs at a temperature of 100, 110, and $330^{\circ} \mathrm{C}$ which corresponds to loss of lattice water molecule with weight loss of $1.88 \%$ (Cald $1.59 \%$ ) for $\mathrm{Co}$ (II) complex and $3.09 \%$ (Cald $3.22 \%$ ) for $\mathrm{Zn}$ (II) complex, and the loss of $\mathrm{HCl}$ for $\mathrm{Hg}(\mathrm{II})$ complex with weight loss of $5.31 \%$ (Cald $5.33 \%)$, respectively. The second decomposition occurs at 


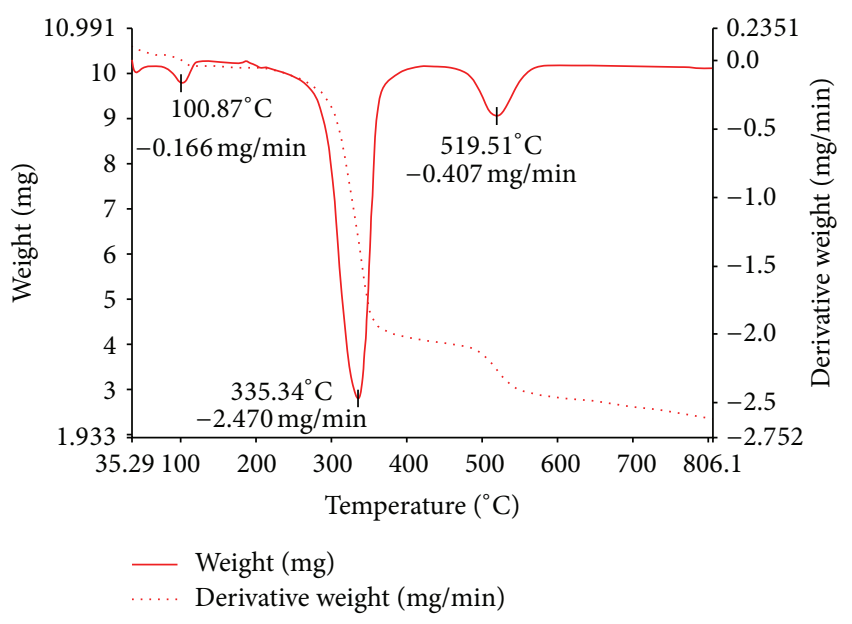

FIgURE 3: TG-DTA curve of $\mathrm{Cu}(\mathrm{II})$ complex.

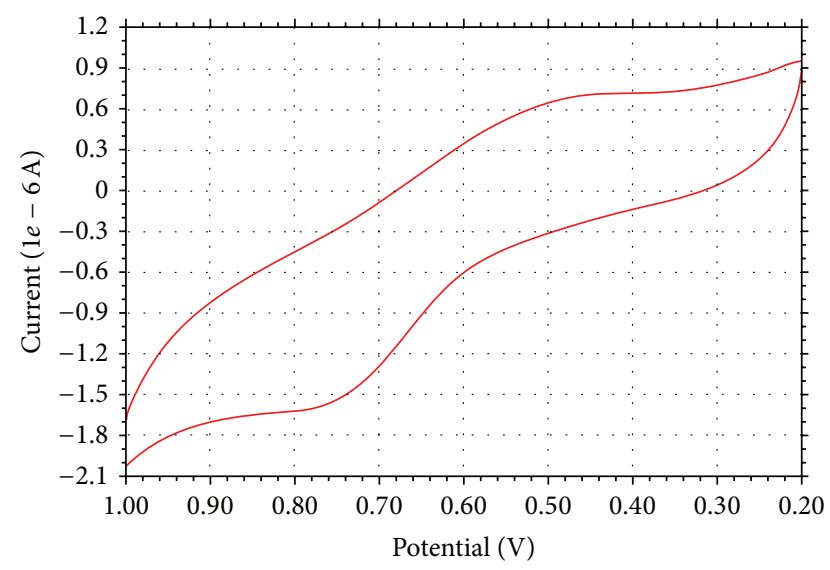

Figure 4: Cyclic voltammogram of $\mathrm{Cu}(\mathrm{II})$ complex at a scan rate of $100 \mathrm{mV} / \mathrm{s}$.

temperatures of 348,340 , and $354^{\circ} \mathrm{C}$ which correspond to the loss of two $\mathrm{C}_{15} \mathrm{H}_{10} \mathrm{~N}_{3} \mathrm{OCl}$ species for $\mathrm{Co}$ (II) complex with weight loss of $61.55 \%$ (Cald. 59.47\%), loss of $\mathrm{C}_{15} \mathrm{H}_{10} \mathrm{~N}_{2} \mathrm{OCl}$ species for $\mathrm{Zn}$ (II) complex with a weight loss of $48.15 \%$ (Cald. 48.25\%), and loss of $\mathrm{C}_{19} \mathrm{H}_{13} \mathrm{ONCl}$ species for $\mathrm{Hg}$ (II) complex with a weight loss of $49.46 \%$ (48.46\%), respectively. Further, these complexes underwent gradual decomposition up to $750-850^{\circ} \mathrm{C}$, corresponds to the loss of remaining organic moiety, leaving behind residue metal oxides of the respective complexes. The percentage metal composition in all the complexes as done by the elemental analysis agrees well with the remaining residual metal oxides in thermal studies.

3.8. Powder X-Ray Diffractions Studies. Although the synthesized metal complexes were soluble in some polar organic solvents (DMSO and DMF), crystals that are suitable for single-crystal studies are not obtained. Powder XRD pattern of $\mathrm{Ni}(\mathrm{II})$ and $\mathrm{Zn}$ (II) complexes are being studied in order to test the degree of crystallinity of the complexes. Powder X-ray diffraction pattern for $\mathrm{Ni}$ (II) complex showed 14 reflections in the range of $5-80^{\circ}(2 \theta)$, which are arised from diffraction of
X-ray by the planes of complex. The interplanar spacing $(d)$ has been calculated by using Bragg's equation, $n \lambda=2 d \sin \theta$. The calculated interplaner $d$-spacing together with relative intensities with respect to most intense peak have been recorded and depicted in Table 6. The unit cell calculations have been calculated for cubic symmetry from the entire important peaks, and $h^{2}+k^{2}+l^{2}$ values were determined. The observed interplaner $d$-spacing values have been compared with the calculated ones, and it was found to be in good agreement. The $h^{2}+k^{2}+l^{2}$ values are $1,3,5,6,10,15,17,39$, $47,83,90,109$, and 138 . It was observed that the presence of forbidden numbers such as 15 and 47 indicates that the $\mathrm{Ni}$ (II) complex may belong to hexagonal or tetragonal systems.

Similar calculations were performed for $\mathrm{Zn}(\mathrm{II})$ complex which showed 15 reflections in the range $5-80^{\circ}(2 \theta)$. The important peaks have been indexed, and observed interplanar $d$-spacing values have been compared with the calculated ones. The unit cell calculations were performed for cubic system, and the $h^{2}+k^{2}+l^{2}$ values were determined. The values are $1,2,3,4,5,7,9,11,13,22,29,41,46$, and 72 . The presence of forbidden number such as 7 indicates the $\mathrm{Zn}$ (II) complex may belong to hexagonal or tetragonal systems (Table 7).

3.9. Electrochemical Study. Electron transfer plays a vital role in governing the pathway of chemical reactions. Cyclic voltammetry is the most versatile electroanalytical technique for the study of electroactive species. The electrochemical behaviour of $\mathrm{Cu}(\mathrm{II})$ complex was investigated in DMF $\left(10^{-3} \mathrm{M}\right)$ solution containing $0.05 \mathrm{M} \mathrm{n}-\mathrm{Bu}_{4} \mathrm{~N}-\mathrm{ClO}_{4}$ as a supporting electrolyte by cyclic voltammetry, and it is the most versatile electroanalytical technique for the study of electroactive species. The cyclic voltammogram of $\mathrm{Cu}$ (II) complex (Figure 4) in DMF at a scan rate of $100 \mathrm{mV} / \mathrm{s}$ shows well-defined redox process corresponding to the formation of $\mathrm{Cu}(\mathrm{II}) / \mathrm{Cu}(\mathrm{I})$ couple at $E_{\mathrm{pa}}=0.76 \mathrm{~V}$ and $E_{\mathrm{pc}}=0.47 \mathrm{~V}$ versus $\mathrm{Ag} / \mathrm{AgCl}$. The peak separation of this couple is found to be quasi-reversible with $\Delta E_{p}=0.29 \mathrm{~V}$, and the ratio of anodic to cathodic peak height was less than one. The difference between forward and backward peak potential can provide a rough evaluation of the degree of the reversibility of one electron transfer reaction. Thus, the analysis of cyclic voltammetric response to $100 \mathrm{mV} / \mathrm{s}, 200 \mathrm{mV} / \mathrm{s}$, and $300 \mathrm{mV} / \mathrm{s}$ scan rates gives the evidence for quasi-reversible one electron redox process. The ratio of anodic to cathodic peak height was less than one, and peak current increases with the increase of square root of the scan rates, establishing diffusion controlled electrode process [52]. From the peak separation value $\Delta E_{p}$ and peak potential increases with higher scan rates, we can suggest that the electrode processes are consistent with the quasi-reversibility of $\mathrm{Cu}(\mathrm{II}) / \mathrm{Cu}(\mathrm{I})$ couple [53].

\subsection{Pharmacological Results}

3.10.1. In Vitro Antimicrobial Activity. The in vitro antimicrobial activity of all the synthesized compounds were screened against E. coli, S. typhi, B. subtilis, and S. aureus bacteria and C. albicans, C. oxysporum, and A. niger fungal strains by minimum inhibitory concentration (MIC) method. The 
TABLE 5: Thermal decomposition of the complexes.

\begin{tabular}{|c|c|c|c|c|c|c|}
\hline \multirow{2}{*}{ Complex number } & \multirow{2}{*}{ Decomposition temp $\left({ }^{\circ} \mathrm{C}\right)$} & \multicolumn{2}{|c|}{$\%$ Weight loss } & \multicolumn{2}{|c|}{ Metal oxide \% } & \multirow{2}{*}{ Inference } \\
\hline & & Obsd & Cald & Obsd & Cald & \\
\hline \multirow{4}{*}{ Cu complex } & 100 & 1.51 & 1.87 & - & - & Loss of lattice water molecule \\
\hline & 335 & 61.55 & 59.47 & - & - & Loss due to two indole $\left(2 \mathrm{C}_{15} \mathrm{H}_{10} \mathrm{~N}_{3} \mathrm{OCl}\right)$ species \\
\hline & 519 & 27.88 & 27.87 & - & - & Loss due to $2 \mathrm{C}_{4} \mathrm{H}_{4}$ \\
\hline & Upto 750 & - & - & 8.28 & 8.10 & Loss due to remaining organic moiety \\
\hline \multirow{3}{*}{ Co complex } & 100 & 1.88 & 1.59 & - & - & Loss of lattice water molecule \\
\hline & 348 & 61.55 & 59.47 & - & - & Loss due to two indole $\left(2 \mathrm{C}_{15} \mathrm{H}_{10} \mathrm{~N}_{3} \mathrm{OCl}\right)$ species \\
\hline & Upto 750 & - & - & 8.19 & 8.05 & Loss due to remaining organic moiety \\
\hline \multirow{3}{*}{ Zn complex } & 110 & 3.09 & 3.22 & - & - & Loss of lattice water molecule \\
\hline & 340 & 48.15 & 48.25 & - & - & Loss due to $\mathrm{C}_{15} \mathrm{H}_{10} \mathrm{~N}_{2} \mathrm{OCl}$ \\
\hline & Upto 750 & - & - & 14.96 & 14.29 & Loss due to organic moiety \\
\hline \multirow{3}{*}{ Hg complex } & 330 & 5.31 & 5.33 & - & - & Loss due to $\mathrm{HCl}$ \\
\hline & 354 & 49.46 & 48.46 & - & - & Loss due to $\mathrm{C}_{19} \mathrm{H}_{13} \mathrm{ONCl}$ species \\
\hline & Upto 850 & - & - & 32.25 & 32.09 & Loss due to remaining organic moiety \\
\hline
\end{tabular}

TABLE 6: Powder X-ray diffraction data of $\mathrm{Ni}(\mathrm{II})$ complex.

\begin{tabular}{lccccccccc}
\hline Peak & $2 \theta$ & $\theta$ & $\operatorname{Sin} \theta$ & $\operatorname{Sin}^{2} \theta$ & $h^{2}+k^{2}+l^{2}\left(\operatorname{Sin}^{2} \theta / \mathrm{CF}\right)$ & $h k l$ & $d$ & Cald. & Obsd. \\
\hline 1 & 6.086 & 3.043 & 0.0530 & 0.00281 & $1.000(1)$ & 100 & 14.5333 & 14.53 & 14.53 \\
2 & 7.385 & 3.692 & 0.0643 & 0.00414 & $1.473(1)$ & 110 & 11.9797 & 14.53 & 14.53 \\
3 & 11.123 & 5.561 & 0.0969 & 0.00939 & $3.341(3)$ & 111 & 7.9494 & 14.53 & 14.53 \\
4 & 12.964 & 6.482 & 0.1128 & 0.01274 & $4.533(5)$ & 210 & 6.8289 & 14.53 & 14.53 \\
5 & 14.863 & 7.431 & 0.1293 & 0.01672 & $5.950(6)$ & 211 & 5.9574 & 14.53 & 14.53 \\
6 & 19.509 & 9.754 & 0.1694 & 0.02870 & $10.213(10)$ & 310 & 4.5472 & 14.53 & 14.53 \\
7 & 23.902 & 11.951 & 0.2070 & 0.04288 & $15.259(15)$ & - & 3.7212 & 14.53 \\
8 & 25.570 & 12.785 & 0.2212 & 0.04897 & $17.427(17)$ & 322 & 3.4823 & 14.53 \\
9 & 38.460 & 19.230 & 0.3293 & 0.10847 & $38.601(39)$ & - & 2.3392 & 14.53 \\
10 & 42.710 & 21.355 & 0.3641 & 0.13260 & $47.188(47)$ & - & 2.1156 & 14.53 & 14.53 \\
11 & 57.670 & 28.835 & 0.4822 & 0.23260 & $82.775(83)$ & - & 1.5974 & 14.53 \\
12 & 60.383 & 30.191 & 0.5028 & 0.25289 & $90.000(90)$ & 754 & 1.5320 & 14.53 \\
13 & 67.305 & 33.652 & 0.5541 & 0.30707 & $109.27(109)$ & - & 1.3901 & 14.53 \\
14 & 77.026 & 38.513 & 0.6226 & 0.38774 & $137.98(138)$ & 875 & 1.2372 & 14.53 \\
\hline
\end{tabular}

minimum inhibitory concentration (MIC) profiles of all the compounds against bacteria and fungi are summarized in Table 8. The MIC values indicated that all the complexes exhibited promising results than the ligand against mentioned microorganisms, and this activity enhanced on coordination with the metal ions. This enhancement in the activity may be rationalized on the basis that ligands mainly possess $\mathrm{C}=\mathrm{N}$ bond. The enhanced activity of the complexes over the ligand can be explained on the basis of chelation theory [54, 55]. It is observed that, in a complex, the positive charge of the metal is partially shared with the donor atoms present in the ligand, and there may be $\pi$-electron delocalization over the whole chelating [56]. This increases the lipophilic character of the metal chelate and favors its permeation through the lipoid layer of the bacterial membranes. The heterocyclic Schiff bases with different functional groups have greater tendency to interact with nucleoside bases even after complexation with metal ion or with the essential metal ions present in the biosystem can act as a promising bactericides because they always tend to interact with enzymatic functional groups, in order to achieve higher coordination numbers [57]. There are also other factors which increase the activity, namely, solubility, conductivity, and bond length between the metal and the ligand.

3.10.2. DNA Cleavage Activity. The representative Schiff base HL and its metal complexes are studied for their DNA cleavage activity by the agarose gel electrophoresis method against DNA of E. coli. The characterization of DNA recognition by transition metal complex has been aided by the DNA cleavage chemistry that is associated with redox-active or photoactivated metal complexes [58]. The electrophoresis analysis clearly revealed that the Schiff base and their metal complexes have acted on DNA as there was a difference in molecular weight between the control and the treated DNA samples. The difference was observed in the bands of lanes of complexes compared with the control DNA of E. coli 
TABLe 7: Powder X-ray diffraction data of Zn(II) complex.

\begin{tabular}{|c|c|c|c|c|c|c|c|c|c|}
\hline \multirow{2}{*}{ Peak } & \multirow{2}{*}{$2 \theta$} & \multirow{2}{*}{$\theta$} & \multirow{2}{*}{$\operatorname{Sin} \theta$} & \multirow{2}{*}{$\operatorname{Sin}^{2} \theta$} & \multirow{2}{*}{$h^{2}+k^{2}+l^{2}\left(\operatorname{Sin}^{2} \theta / \mathrm{CF}\right)$} & \multirow{2}{*}{$h k l$} & \multicolumn{2}{|c|}{$d$} & \multirow{2}{*}{$a$ in $\AA$} \\
\hline & & & & & & & Cald. & Obsd. & \\
\hline 1 & 6.953 & 3.4765 & 0.0606 & 0.00367 & $1.000(1)$ & 100 & 12.7112 & 12.7028 & 12.71 \\
\hline 2 & 7.786 & 3.8930 & 0.0678 & 0.00460 & $1.253(1)$ & 100 & 11.3613 & 11.3461 & 12.71 \\
\hline 3 & 10.094 & 5.0470 & 0.0879 & 0.00739 & $2.013(2)$ & 110 & 8.7633 & 8.7561 & 12.71 \\
\hline 4 & 12.115 & 6.0575 & 0.1055 & 0.01113 & $3.032(3)$ & 111 & 7.3014 & 7.2995 & 12.71 \\
\hline 5 & 14.757 & 7.3785 & 0.1284 & 0.01649 & $4.493(4)$ & 200 & 5.9992 & 5.998 & 12.71 \\
\hline 6 & 16.104 & 8.0522 & 0.1400 & 0.01962 & $5.346(5)$ & 210 & 5.5021 & 5.499 & 12.71 \\
\hline 7 & 18.325 & 9.1625 & 0.1592 & 0.02535 & $6.907(7)$ & - & 4.8385 & 4.8374 & 12.71 \\
\hline 8 & 20.999 & 10.199 & 0.1770 & 0.03135 & $8.542(9)$ & 221,300 & 4.3519 & 4.3501 & 12.71 \\
\hline 9 & 23.474 & 11.737 & 0.2034 & 0.04137 & $11.272(11)$ & 311 & 3.7871 & 3.7867 & 12.71 \\
\hline 10 & 25.247 & 12.623 & 0.2185 & 0.04776 & $13.013(13)$ & 320 & 3.5254 & 3.5247 & 12.71 \\
\hline 11 & 32.675 & 16.3375 & 0.2812 & 0.07912 & $21.558(22)$ & 332 & 2.7393 & 2.7384 & 12.71 \\
\hline 12 & 38.105 & 19.052 & 0.3264 & 0.1065 & $29.032(29)$ & 520 & 2.3599 & 2.3597 & 12.71 \\
\hline 13 & 45.866 & 22.933 & 0.3896 & 0.1518 & $41.370(41)$ & 621 & 1.9771 & 1.9768 & 12.71 \\
\hline 14 & 48.416 & 24.208 & 0.4100 & 0.1681 & $45.814(46)$ & 631 & 1.8780 & 1.8785 & 12.71 \\
\hline 15 & 61.823 & 30.911 & 0.5137 & 0.2639 & $71.907(72)$ & 660 & 1.4995 & 1.4994 & 12.71 \\
\hline
\end{tabular}

TABLE 8: Minimum inhibitory concentration $\left(\mathrm{MIC} \mu \mathrm{g} \mathrm{mL}^{-1}\right)$ of ligand and its metal complexes.

\begin{tabular}{|c|c|c|c|c|c|c|c|}
\hline \multirow{2}{*}{ Compounds } & \multicolumn{7}{|c|}{ MIC value in $\mu \mathrm{g} \mathrm{mL}^{-1}$ (zone of inhibition in $\mathrm{mm}$ ) } \\
\hline & E. coli & S. aureus & B. subtilis & S. typhi & C. albicans & C. oxysporum & A. niger \\
\hline HL & 50 & 75 & 50 & 100 & 75 & 50 & 50 \\
\hline $\mathrm{Cu}$ complex & 12.50 & 25 & 25 & 50 & 25 & 12.50 & 12.50 \\
\hline Co complex & 25 & 50 & 12.50 & 50 & 12.50 & 25 & 25 \\
\hline Ni complex & 12.50 & 25 & 25 & 50 & 25 & 12.50 & 25 \\
\hline Zn complex & 25 & 50 & 25 & 75 & 50 & 25 & 25 \\
\hline Cd complex & 12.50 & 12.50 & 12.50 & 25 & 12.50 & 25 & 12.50 \\
\hline Hg complex & 25 & 12.50 & 25 & 50 & 25 & 25 & 12.50 \\
\hline Gentamycin & 12.50 & 12.50 & 12.50 & 12.50 & - & - & - \\
\hline Fluconazole & - & - & - & - & 12.50 & 12.50 & 12.50 \\
\hline
\end{tabular}

$\mathbf{H L}=$ ligand.

(Figure 5) which is due to the relaxation of circular DNA into linear form. This shows that the control DNA alone does not show any apparent cleavage, whereas the Schiff base and its complexes do show. The lane $\mathrm{Cu}$ shows complete cleavage of DNA of $E$. coli, whereas the other complexes have shown partial cleavage. The result indicates the important role of coordination of nitrogen and oxygen to the metal in these isolated DNA cleavage reactions. As the compound was observed to cleave the DNA, it can be concluded that the compounds inhibit the growth of the pathogenic organism by cleaving the DNA of E. coli.

3.10.3. Antioxidant Assay (DPPH Free Radical Scavenging Activity). The newly synthesized Schiff base and its metal complexes were screened for free radical scavenging activity by DPPH method. Antioxidant activity of these compounds was investigated by measuring radical scavenging effect of DPPH radicals. The results of the free radical scavenging activity of the compounds at different concentrations are shown in Figure 6. It is evident from the results that the

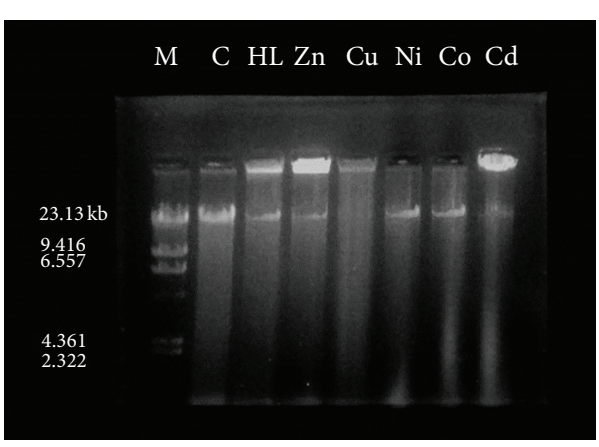

FIgURE 5: DNA cleavage of E. coli genome. M: standard molecular weight marker; C: control. Lane $\mathrm{HL}, \mathrm{Zn}, \mathrm{Cu}, \mathrm{Ni}, \mathrm{Co}$, and $\mathrm{Cd}$ treated DNA of $E$. coli genome with respective compounds.

free radical scavenging activity of these compounds was concentration dependent. Among the examined compounds $\mathrm{Cu}(\mathrm{II}), \mathrm{Cd}(\mathrm{II}), \mathrm{Ni}(\mathrm{II})$, and $\mathrm{Co}(\mathrm{II})$ complexes have exhibited good scavenging activity. Whereas, $\mathrm{Hg}$ (II) and $\mathrm{Zn}$ (II) have 


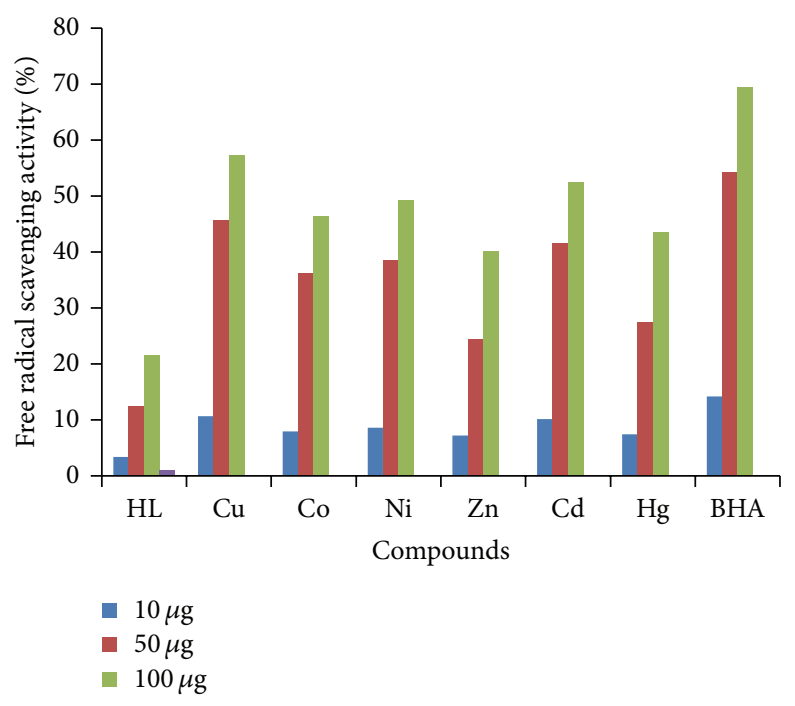

FIgURE 6: Antioxidant results of ligand and its complexes.

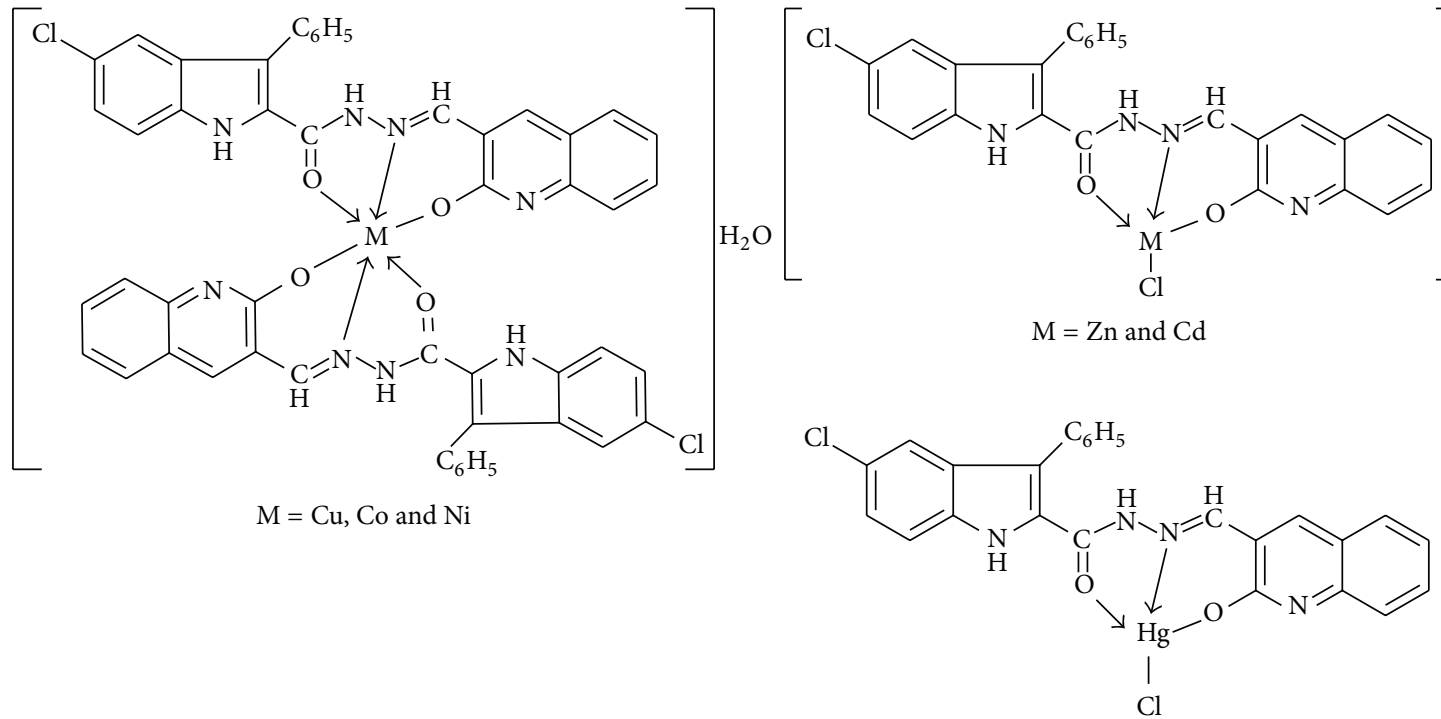

Figure 7: Proposed structures of metal complexes.

shown moderate activity. All the metal complexes have exhibited higher scavenging activity than the Schiff base HL. The marked antioxidant activity of the metal complexes, in comparison to free Schiff base HL, could be due to the coordination of metal with azomethine nitrogen, carbonyl oxygen of amide function attached to the 2-position of indole, and oxygen of enolized amide function of quinolinone moiety vai deprotonation. In case of the above test compounds, the hydrogen of azomethine is more acidic than the hydrogen of the indole NH. Hence, hydrogen of azomethine could be easily donated to the DPPH free radical and convert itself into the stable free radical.

\section{Conclusions}

On the basis of the above results the Schiff base HL acts as tridentate $(\mathrm{ONO})$ chelating agent coordinate with metal ions through the carbonyl group of amide function attached to 2-position of indole, azomethine nitrogen, and oxygen atom of the enolized amide function of quinolinone moiety via deprotonation. Analytical, spectral, and magnetic studies revealed mononuclear nature of the complexes. The probable structures of the metal complexes are shown in Figure 7. The $\mathrm{Cu}(\mathrm{II}), \mathrm{Co}(\mathrm{II})$, and $\mathrm{Ni}(\mathrm{II})$ complexes exhibited octahedral geometry whereas $\mathrm{Zn}(\mathrm{II}), \mathrm{Cd}(\mathrm{II})$, and $\mathrm{Hg}$ (II) complexes exhibited tetrahedral geometry. The antimicrobial activity of the Schiff base $\mathrm{HL}$ is enhanced upon complexation with metal ions particularly $\mathrm{Cu}(\mathrm{II}), \mathrm{Co}(\mathrm{II})$, and $\mathrm{Ni}(\mathrm{II})$ showed promising activity compared to Schiff base and proved to be essential for the growth-inhibitor effect. The DNA cleavage studies revealed that the $\mathrm{Cu}(\mathrm{II})$ complex has shown complete cleavage of genomic DNA of $E$. coli. The results of antioxidant activity experiment clearly indicate that among the test 
compounds $\mathrm{Cu}(\mathrm{II}), \mathrm{Cd}(\mathrm{II}), \mathrm{Ni}(\mathrm{II})$, and $\mathrm{Co}(\mathrm{II})$ complexes have exhibited good scavenging activity compared to the standard.

\section{Acknowledgments}

The authors are thankful to the Professor and Chairman, Department of Chemistry, Gulbarga, University, Gulbarga for providing the laboratory facilities. The authors are thankful to STIC Cochin University, SAIF IISC Bangalore, CDRI Lucknow, Chairman, Department of Material Science, Gulbarga University, Gulbarga, for providing spectral data, and the BioGenics Research and Training Centre in Biotechnology, Hubli, for biological activities.

\section{References}

[1] U. Misra, A. Hitkari, A. K. Saxena, S. Gurtu, and K. Shanker, "Biologically active indolylmethyl-1,3,4-oxadiazoles, 1,3,4thiadiazoles, 4H-1,3,4-triazoles and 1,2,4-triazines," European Journal of Medicinal Chemistry, vol. 31, no. 7-8, pp. 629-634, 1996.

[2] P. Rani, V. K. Srivastava, and A. Kumar, "Synthesis and antiinflammatory activity of heterocyclic indole derivatives," European Journal of Medicinal Chemistry, vol. 39, no. 5, pp. 449-452, 2004.

[3] A. El-Gendy Adel, A. Abdou Naida, Z. Sarhan El-Taher, and A. El-Banna Hosney, "Synthesis and biological activity of some new spio-[indoline-3, $2^{\prime}$-thiazolidine]-2,4,-diones," Alexandria Journal of Pharmaceutical Science, vol. 7, pp. 99-103, 1993.

[4] N. Karali, A. Gürsoy, F. Kandemirli et al., "Synthesis and structure-antituberculosis activity relationship of $1 \mathrm{H}$-indole2,3-dione derivatives," Bioorganic and Medicinal Chemistry, vol. 15, no. 17, pp. 5888-5904, 2007.

[5] A. Dandia, V. Sehgal, and P. Singh, "Synthesis of fluorine containing 2-aryl-3-pyrazolyl/pyranyl/isoxazolinyl-indole derivative as antifungal and antibacterial agents," Indian Journal of Chemistry Section B, vol. 32, pp. 1288-1291, 1993.

[6] A. S. Kalgutkar, B. C. Crews, S. Saleh, D. Prudhomme, and L. J. Marnett, "Indolyl esters and amides related to indomethacin are selective COX-2 inhibitors," Bioorganic and Medicinal Chemistry, vol. 13, no. 24, pp. 6810-6822, 2005.

[7] S. Olgen and D. Nebioglu, "Synthesis and biological evaluation of N-substituted indole esters as inhibitors of cyclo-oxygenase2 (COX-2)," Farmaco, vol. 57, no. 8, pp. 677-683, 2002.

[8] I. A. Leneva, N. I. Fadeeva, and I. T. Fedykina, Proceedings of the 7th International Conference on Antiviral Research, Abstract 187, 1994.

[9] A. Y. Merwade, S. B. Rajur, and L. D. Basanagoudar, "Synthesis and antiallergic acitivities of 10-substituted-4-chloro-12methyl(or phenyl)-1,2-dihydroquinoxalino[1,2-a]indoles," Indian Journal of Chemistry B, vol. 29, no. 12, pp. 1113-1117, 1990.

[10] A. E. Fernandez and V. A. Monge, "Spanish Patent 400,436," Chemical Abstract, 83, 1142059, Spanish Patent and Trademark Office, 1975.

[11] N. Ergenç, N. S. Günay, and R. Demirdamar, "Synthesis and antidepressant evaluation of new 3-phenyl-5-sulfonamidoindole derivatives," European Journal of Medicinal Chemistry, vol. 33, no. 2, pp. 143-148, 1998.

[12] R. E. Moore, C. Cheuk, X. Q. G. Yang et al., "Hapalindoles, antibacterial and antimycotic alkaloids from the cyanophyte
Hapalosiphon fontinalis," Journal of Organic Chemistry, vol. 52, no. 6, pp. 1036-1043, 1987.

[13] V. K. Pandey, S. Tusi, R. Misra, and R. Shukla, "A chemical strategy for the construction of quinoline isoquinoline core units," Indian Journal of Chemistry B, vol. 49, no. 1, pp. 107-111, 2010.

[14] A. Mital, V. S. Negi, and U. Ramachandran, "Synthesis and antimycobacterial activities of certain trifluoromethyl-aminoquinoline derivatives," Arkivoc, vol. 2006, no. 10, pp. 220-227, 2006.

[15] R. U. Pokalwar, R. V. Hangarge, P. V. Maske, and M. S. Shingare, "Synthesis and antibacterial activities of $\alpha$-hydroxyphosphonates and $\alpha$-acetyloxyphosphonates derived from 2chloroquinoline-3-carbaldehyde," Arkivoc, vol. 2006, no. 11, pp. 196-204, 2006.

[16] A. Srivastava, A. Chandra, and R. M. Singh, "Thiophene-fused quinoline analogues: facile synthesis of 3-amino-2-cyanothieno [2,3-b] quinolines from 2-chloro-3-cyanoquinolines," Indian Journal of Chemistry B, vol. 44, no. 10, pp. 2077-2081, 2005.

[17] P. K. Dubey, S. Srinivas Rao, and V. Aparna, "Synthesis of some novel 3-(2-chloro-3-quinolyl)-5-phenyl [1,3] thiazolo [2,3-c] $[1,2,4]$ triazoles," Heterocyclic Communications, vol. 9, no. 3, pp. 281-286, 2003.

[18] P. R. Reddy, K. S. Rao, and B. Satyanarayana, "Synthesis and DNA cleavage properties of ternary $\mathrm{Cu}$ (II) complexes containing histamine and amino acids," Tetrahedron Letters, vol. 47, no. 41, pp. 7311-7315, 2006.

[19] A. P. Kourounakis, D. Galanakis, K. T. Siakitzis, E. A. Rekka, and P. N. Kourounakis, "Synthesis and pharmacological evaluation of novel derivatives of anti-inflammatory drugs with increased antioxidant and anti-inflammatory activities," Drug Development Research, vol. 47, pp. 9-16, 1999.

[20] M. E. Buyukokuroglu, I. Gulcin, M. Oktay, and O. I. Kufrevioglu, "In vitroantioxidant properties of dantrolene sodium," Pharmacological Research, vol. 44, no. 6, pp. 491-494, 2001.

[21] M. E. Bravo-Gómez, J. C. García-Ramos, I. Gracia-Mora, and L. Ruiz-Azuara, "Antiproliferative activity and QSAR study of copper(II) mixed chelate $\left[\mathrm{Cu}(\mathrm{N}-\mathrm{N})\right.$ (acetylacetonato) $\mathrm{NO}_{3}$ and $[\mathrm{Cu}(\mathrm{N}-\mathrm{N})$ (glycinato) $] \mathrm{NO}_{3}$ complexes, (Casiopeínas)," Journal of Inorganic Biochemistry, vol. 103, no. 2, pp. 299-309, 2009.

[22] S. B. Bukhari, S. Memon, M. M. Tahir, and M. I. Bhanger, "Synthesis, characterization and investigation of antioxidant activity of cobalt-quercetin complex," Journal of Molecular Structure, vol. 892, no. 1-3, pp. 39-46, 2008.

[23] Y. Jadegoud, O. B. Ijare, N. N. Mallikarjuna, S. D. Angadi, and B. H. M. Mruthyunjayaswamy, "Synthesis and antimicrobial activity of copper-, cobalt- and nickel(II) complexes with Schiff bases," Journal of the Indian Chemical Society, vol. 79, no. 12, pp. 921-924, 2002.

[24] B. H. M. Mruthyunjayaswamy, Y. Jadegoud, O. B. Ijare, S. G. Patil, and S. M. Kudari, "Synthesis, characterization and antimicrobial activity of macrocylic phenoxo-bridged di- and tetra-nuclear complexes from N,N-bis[2,6-diiminomethyl-4methyl-1-hydroxyphenyl] succinoyl/sebacoyldicarboxamides," Transition Metal Chemistry, vol. 30, no. 2, pp. 234-242, 2005.

[25] B. H. M. Mruthyunjayaswamy, O. B. Ijare, and Y. Jadegoud, "Synthesis, characterization and biological activity of symmetric dinuclear complexes derived from a novel macrocyclic compartmental ligand," Journal of the Brazilian Chemical Society, vol. 16, no. 4, pp. 783-789, 2005. 
[26] Y. Jadegoud, O. B. Ijare, B. S. Somashekar, G. A. N. Gowda, and B. H. M. Mruthyunjayaswamy, "Synthesis, characterization and antimicrobial activity of homodinuclear complexes derived from 2,6-bis [ $3^{\prime}$-methyl- $2^{\prime}$-carboxamidyliminomethyl $\left(6^{\prime}, 7^{\prime}\right)$ benzindole]-4-methylphenol, an end-off compartmental ligand," Journal of Coordination Chemistry, vol. 61, no. 4, pp. 508-527, 2008.

[27] F. Rahaman, B. Hiremath, S. M. Basavarajaiah, B. H. M. Jayakumarswamy, and B. H. M. Mruthyunjayaswamy, "Synthetic, spectral, thermal and antimicrobial activity studies of some transition metal complexes derived from 2hydroxy-methylbenzaldehyde N-( $4^{\prime}$ - phenyl-1', $3^{\prime}$-thiazol-2' -yl $)$ semicarbazone," Journal of the Indian Chemical Society, vol. 85, no. 4, pp. 381-386, 2008.

[28] F. Rahaman, O. B. Ijare, Y. Jadegoud, and B. H. M. Mruthyunjayaswamy, "Phenoxo-bridged symmetrical homobinuclear complexes derived from an "end-off” compartmental ligand, 2,6-bis [5' -chloro- $3^{\prime}$-phenyl- $1 \mathrm{H}$-indole- $2^{\prime}$-carboxamidyliminomethyl]-4-methylphenol," Journal of Coordination Chemistry, vol. 62, no. 9, pp. 1457-1467, 2009.

[29] A. I. Vogel, A Text Book of Quantitative Inorganic Analysis, Longman ELBS, London, UK, 3rd edition, 1968.

[30] S. P. Hiremath, B. H. M. Mruthyunjayaswamy, and M. G. Purohit, "Synthesis of substituted 2-aminoindolees and 2( $2^{\prime}$-Phenyl-1', 3',4'-oxadiazolyl)aminoindoles," Indian Journal of Chemistry Section B, vol. 16, pp. 789-792, 1978.

[31] A. K. Sadana, Y. Mirza, K. R. Aneja, and O. Prakash, "Hypervalent iodine mediated synthesis of 1-aryl/hetryl-1,2,4-triazolo[4,3-a] pyridines and 1-aryl/hetryl 5-methyl-1,2,4-triazolo[4,3-a]quinolines as antibacterial agents," European Journal of Medicinal Chemistry, vol. 38, no. 5, pp. 533-536, 2003.

[32] T. A. Brown, Essential Molecular Biology: A Practical Approach, vol. 1, Oxford University Press, New York, NY, USA, 1990.

[33] J. Sambrook, E. F. Fritsch, and T. Maniatis, Molecular Cloning: A Laboratory Manual, Cold Spring Harbor Laboratory, Cold Spring Harbor, New York, USA, 2nd edition, 1989.

[34] R. P. Singh, K. N. Chidambara Murthy, and G. K. Jayaprakasha, "Studies on the antioxidant activity of pomegranate (Punica granatum) peel and seed extracts using in vitro models," Journal of Agricultural and Food Chemistry, vol. 50, no. 1, pp. 81-86, 2002.

[35] W. J. Geary, "The use of conductivity measurements in organic solvents for the characterisation of coordination compounds," Coordination Chemistry Reviews, vol. 7, no. 1, pp. 81-122, 1971.

[36] B. Srinivas, N. Arulsamy, and P. S. Zacharias, "Catalytic and magnetic properties of a new series of binuclear copper(II) complexes," Polyhedron, vol. 10, no. 7, pp. 731-736, 1991.

[37] C. Jayabalakrishnan and K. Natarajan, "Ruthenium(II) carbonyl complexes with tridentate Schiff bases and their antibacterial activity," Transition Metal Chemistry, vol. 27, no. 1, pp. 75-79, 2002.

[38] S. Chandra and L. K. Gupta, "EPR, mass, IR, electronic, and magnetic studies on copper(II) complexes of semicarbazones and thiosemicarbazones," Spectrochimica Acta A, vol. 61, no. 1-2, pp. 269-275, 2005.

[39] V. B. Rana, P. C. Jain, M. P. Swami, and A. K. Srivastava, "Thiosemicabazones as ligands-I. Spectrochemical studies on trivalent metal complexes of 1-phenyl-orthohydroxy-4benzamido thiosemicarbazone," Journal of Inorganic and Nuclear Chemistry, vol. 37, no. 7-8, pp. 1826-1828, 1975.

[40] K. Abe, K. Matsufuji, M. Ohba, and H. Okawa, "Site specificity of metal ions in heterodinuclear complexes derived from an "end-off" compartmental ligand," Inorganic Chemistry, vol. 41, no. 17, pp. 4461-4467, 2002.

[41] R. A. Rai, "Metal complexes of 5-(o)hydroxyphenyl-1,3,4-oxadiazole-2-thione," Journal of Inorganic and Nuclear Chemistry, vol. 42, no. 3, pp. 450-453, 1980.

[42] A. E. Underhill and D. E. Billing, "Calculations of the racah parameter B for nickel (II) and cobalt (II) compounds [11]," Nature, vol. 210, no. 5038, pp. 834-835, 1966.

[43] D. N. Satyanarayana, Electronic Absorption Spectroscopy and Related Techniques, University Press India Limited, New Delhi, India, 2001.

[44] K. Shivakumar, S. Shashidhar, P. Vithal Reddy, and M. B. Halli, "Synthesis, spectral characterization and biological activity of benzofuran Schiff bases with $\mathrm{Co}(\mathrm{II}), \mathrm{Ni}(\mathrm{II}), \mathrm{Cu}(\mathrm{II}), \mathrm{Zn}(\mathrm{II})$, $\mathrm{Cd}(\mathrm{II})$ and $\mathrm{Hg}(\mathrm{II})$ complexes," Journal of Coordination Chemistry, vol. 61, no. 14, pp. 2274-2287, 2008.

[45] D. P. Singh, R. Kumar, V. Malik, and P. Tyagi, "Synthesis and characterization of complexes of $\mathrm{Co}(\mathrm{II}), \mathrm{Ni}(\mathrm{II}), \mathrm{Cu}(\mathrm{II}), \mathrm{Zn}(\mathrm{II})$, and Cd(II) with macrocycle 3,4,11,12-tetraoxo-1,2,5,6,9,10,13,14octaaza-cyclohexadeca-6,8,14,16-tetraene and their biological screening," Transition Metal Chemistry, vol. 32, no. 8, pp. 10511055, 2007.

[46] N. N. Greenwood and A. Earnshaw, Chemistry of the Elements, Heimemann, Oxford, UK, 2nd edition, 1997.

[47] T. R. Rao and A. Prasad, "Synthesis and spectral studies on 3d metal complexes of mesogenic schiff base ligands. Part 1. Complexes of N-(4-butylphenyl) salicylaldimine," Synthesis and Reactivity in Inorganic, Metal-Organic and Nano-Metal Chemistry, vol. 35, no. 4, pp. 299-304, 2005.

[48] S. Balasubramanian and C. N. Krishnan, "Synthesis and characterization of five-coordinate macrocyclic complexes of nickel(II) and copper(II)," Polyhedron, vol. 5, no. 3, pp. 669-675, 1986.

[49] B. T. Thaker, P. K. Tandel, A. S. Patel, C. J. Vyas, M. S. Jesani, and D. M. Patel, "Synthesis and mesomorphic characterization of $\mathrm{Cu}(\mathrm{II}), \mathrm{Ni}(\mathrm{II})$ and $\mathrm{Pd}(\mathrm{II})$ complexes with azomethine and chalcone as bridging group," Indian Journal of Chemistry A, vol. 44, no. 2, pp. 265-270, 2005.

[50] D. Kilveson, "Publications of Daniel Kivelson," Journal of Physical Chemistry B, vol. 101, pp. 8631-8634, 1997.

[51] B. J. Hathaway and D. E. Billing, "The electronic properties and stereochemistry of mono-nuclear complexes of the copper(II) ion," Coordination Chemistry Reviews, vol. 5, no. 2, pp. 143-207, 1970.

[52] A. J. Bard and L. R. Faulkner, Electrochemical Methods, Wiley, New York, NY, USA, 2nd edition, 2001.

[53] S. A. Patil, V. H. Naik, A. D. Kulkarni, and P. S. Badami, "Spectroscopic, DNA cleavage and antimicrobial studies of $\mathrm{Co}(\mathrm{II}), \mathrm{Ni}(\mathrm{II})$ and $\mathrm{Cu}(\mathrm{II})$ complexes of sulfur donor schiff bases," Journal of Sulfur Chemistry, vol. 31, no. 2, pp. 109-121, 2010.

[54] A. K. Sharma and S. Chandra, "Complexation of nitrogen and sulphur donor Schiff's base ligand to $\mathrm{Cr}$ (III) and $\mathrm{Ni}(\mathrm{II})$ metal ions: synthesis, spectroscopic and antipathogenic studies," Spectrochimica Acta A, vol. 78, no. 1, pp. 337-342, 2011.

[55] Z. H. Chohan, M. Arif, M. A. Akhtar, and C. T. Supuran, "Metal-based antibacterial and antifungal agents: synthesis, characterization, and in vitro biological evaluation of $\mathrm{Co}(\mathrm{II})$, $\mathrm{Cu}(\mathrm{II}), \mathrm{Ni}(\mathrm{II})$, and $\mathrm{Zn}$ (II) complexes with amino acid-derived compounds," Bioinorganic Chemistry and Applications, vol. 2006, Article ID 83131, 13 pages, 2006. 
[56] Z. H. A. El-Wahab, M. M. Mashaly, A. A. Salman, B. A. ElShetary, and A. A. Faheim, "Co(II), Ce(III) and UO2(VI) bis-salicylatothiosemicarbazide complexes: binary and ternary complexes, thermal studies and antimicrobial activity," Spectrochimica Acta A, vol. 60, no. 12, pp. 2861-2873, 2004.

[57] K. R. K. Reddy, P. Suneetha, C. S. Karigar, N. H. Manjunath, and K. N. Mahendra, "Cobalt(II), Ni(II), Cu(II), Zn(II), CD(II), $\mathrm{Hg}(\mathrm{II}), \mathrm{U} 02(\mathrm{VI})$ and th(IV) complexes from ONNN Schiff base ligand," Journal of the Chilean Chemical Society, vol. 53, no. 4, pp. 1653-1657, 2008.

[58] A. Sitlani, E. C. Long, A. M. Pyle, and J. K. Barton, "DNA photocleavage by phenanthrenequinone diimine complexes of rhodium(III): shape-selective recognition and reaction," Journal of the American Chemical Society, vol. 114, no. 7, pp. 2303-2312, 1992. 

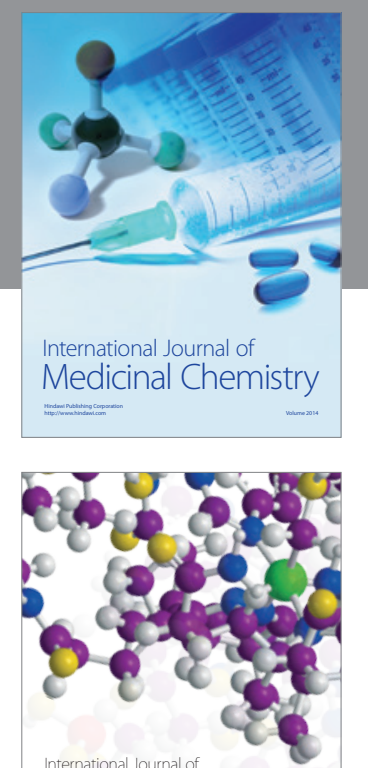

\section{Carbohydrate} Chemistry

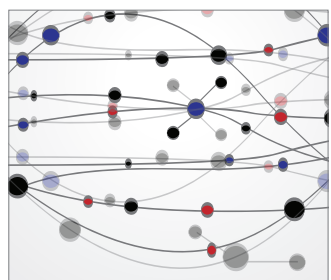

The Scientific World Journal
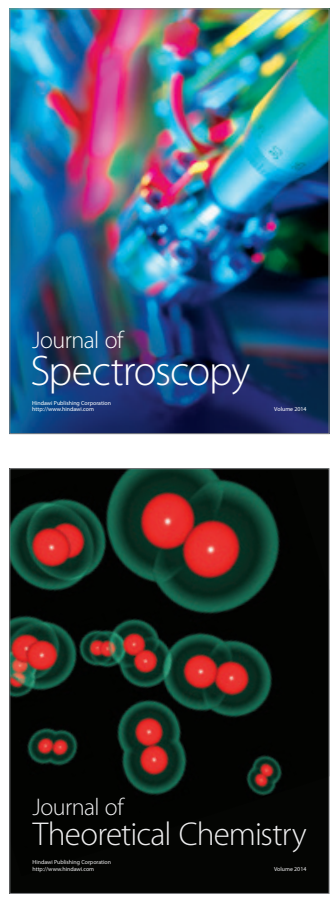
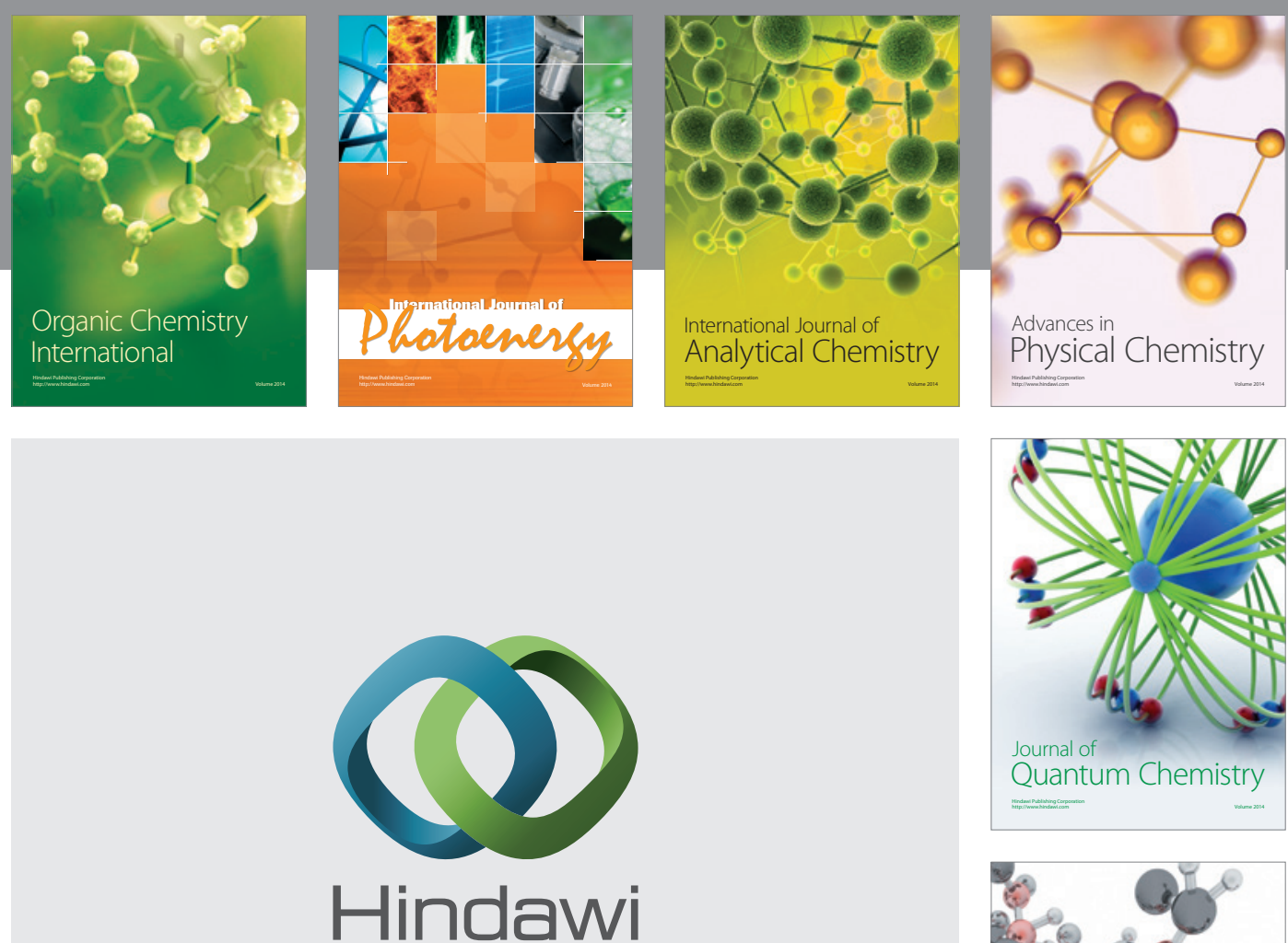

Submit your manuscripts at

http://www.hindawi.com

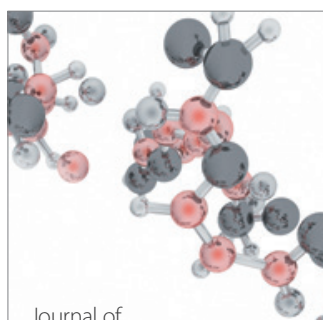

Analytical Methods

in Chemistry

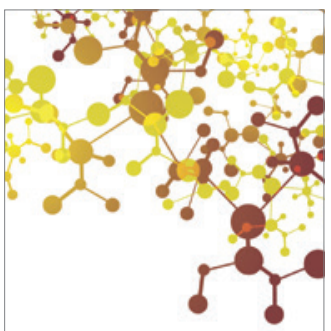

Journal of

Applied Chemistry

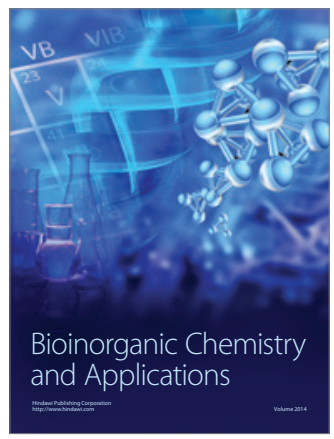

Inorganic Chemistry
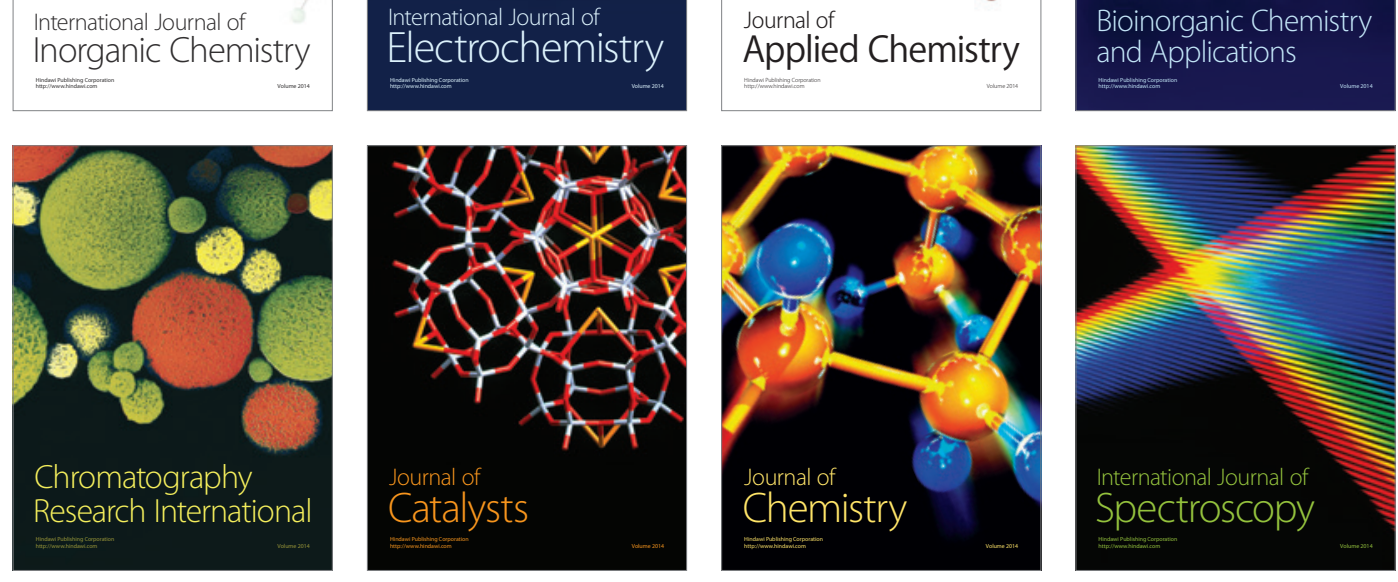